\title{
English Language Bachelor European Law School: Recruitment and Labour Market Position
}

Citation for published version (APA):

Sieben, I. J. P., \& Lintjens, E. L. M. (2006). English Language Bachelor European Law School: Recruitment and Labour Market Position. ROA. ROA Reports No. 003E https://doi.org/10.26481/umarep.2006003E

Document status and date:

Published: 01/01/2006

DOI:

10.26481/umarep.2006003E

Document Version:

Publisher's PDF, also known as Version of record

\section{Please check the document version of this publication:}

- A submitted manuscript is the version of the article upon submission and before peer-review. There can be important differences between the submitted version and the official published version of record.

People interested in the research are advised to contact the author for the final version of the publication, or visit the DOI to the publisher's website.

- The final author version and the galley proof are versions of the publication after peer review.

- The final published version features the final layout of the paper including the volume, issue and page numbers.

Link to publication

\footnotetext{
General rights rights.

- You may freely distribute the URL identifying the publication in the public portal. please follow below link for the End User Agreement:

www.umlib.nl/taverne-license

Take down policy

If you believe that this document breaches copyright please contact us at:

repository@maastrichtuniversity.nl

providing details and we will investigate your claim.
}

Copyright and moral rights for the publications made accessible in the public portal are retained by the authors and/or other copyright owners and it is a condition of accessing publications that users recognise and abide by the legal requirements associated with these

- Users may download and print one copy of any publication from the public portal for the purpose of private study or research.

- You may not further distribute the material or use it for any profit-making activity or commercial gain

If the publication is distributed under the terms of Article $25 \mathrm{fa}$ of the Dutch Copyright Act, indicated by the "Taverne" license above, 
English Language Bachelor European Law School: Recruitment and Labour Market Position

\author{
Inge Sieben \\ Erik Lintjens \\ ROA-R-2006/3E
}




\section{Colophon}

(C) Research Centre for Education and the Labour Market. No part of this publication may be reproduced without the prior permission in writing of the director of the Research Centre for Education and the Labour Market.

\section{Research Centre for Education and the Labour Market}

Faculty of Economics and Business Administration

Maastricht University

\section{Layout}

Secretary ROA, Maastricht

\section{Sales}

Research Centre for Education and the Labour Market email: secretary@roa.unimaas.nl website: www.roa.unimaas.nl

ISBN-IO: 90-532I-43I-3

ISBN-I3: 978-90-532I-43I-2

May 2006 


\section{Contents}

Preface

Management summary $\quad$ vii

1 Introduction 1

1.1 Background 1

1.2 This Report 4

2 Recruitment $\quad 7$

$\begin{array}{ll}2.1 \text { Introduction } & 7\end{array}$

2.2 Background Characteristics $\quad 7$

2.3 Region and Nationality 9

2.4 Languages 13

2.5 Regret and Dropouts 14

3 Labour Market Position $\quad 15$

3.1 Introduction $\quad 15$

$\begin{array}{ll}3.2 \text { Postgraduate Education } & 15\end{array}$

3.3 Labour Market Position 16

3.4 Match between Study Followed and Present Job 17

3.5 Occupations and Branches: in The Netherlands or abroad ? 18

3.6 Expected Developments on the Labour Market 20

4 Students' Opinions $\quad 25$

$\begin{array}{ll}4.1 \text { Introduction } & 25\end{array}$

4.2 The New English Language Bachelor European Law School 27

4.3 Recruitment 32

$\begin{array}{ll}4.4 \text { Labour Market Position } & 40\end{array}$

Appendix A: Classification of University Studies 43

Appendix B: Group Interviews with Students: Topics and Questions 45 



\section{Preface}

Maastricht University is progressively attracting more foreign students and has the ambition to further increase this intake. So far, the Faculty of Law has been contributing to this ambition by offering a number of English language master programmes. In order to increase the number of foreign students in the bachelor phase as well, the Faculty of Law wants to start an English Language Bachelor European Law School.

The Research Centre for Education and the Labour Market (ROA) was asked to conduct a study about the feasibility of this English Language Bachelor European Law School and to explore the recruitment and labour market position of students of the new track. The present report describes the results of this study.

We would like to thank Prof. Mr. A. Kamperman Sanders of the Faculty of Law for initiating the project and for giving very valuable feedback, Mr. Th. Grootjans for his input throughout the entire process and for organizing and participating in the majority of the group interviews, and M. Delnooz and S. Janssen for providing us with information about student enrolment in law studies. In addition, we would like to express our gratitude to the students who were willing to participate in our group interviews and who articulated their opinions about the new English Language Bachelor European Law School and Maastricht University. 



\section{Management summary}

Maastricht University is progressively attracting more foreign students and has the ambition to further increase this intake. So far, the Faculty of Law has been contributing to this ambition by offering a number of English language master programmes. In order to increase the number of foreign students in the bachelor phase as well, the Faculty of Law wants to start an English Language Bachelor European Law School (EELS) alongside the 'classic' bachelor European Law School (ELS).

The 'classic' bachelor European Law School can be described as a double track of Dutch law and European and comparative law. Since courses on Dutch law are taught in Dutch, enrolment is practically limited to Dutch speakers. The new track will offer courses in English and allows students to study European law as a major and several national law systems (e.g. Belgian law, German law, or Dutch law) as minors.

The Research Centre for Education and the Labour Market (ROA) was asked by the Faculty of Law to examine whether their expectations concerning the English Language Bachelor European Law School are feasible. The research builds on two pillars: recruitment and labour market position.

\section{Recruitment}

The recruitment power of the new English Language Bachelor European Law School was analyzed by constructing a 'profile' of students who actually choose European Law School. This profile is based on data from the ROA School-leavers Information System (SIS) 1999-2004. It shows that European Law School cannot be labelled as a typical 'feminine' study, as the percentage of female students $(60 \%)$ is in line with the overall trend in university education. ELS graduates are younger than their counterparts, which might be caused by the fact that they predominantly come from preuniversity education (VWO). Higher Vocational Education (HBO) turns out not to be an important stepping stone. European Law School students are more often born abroad (30\%) than their counterparts in international and European law (II\%) or other university studies (6\%). Dutch students, however, mostly come from the South of the Netherlands. Finally, ELS students are better at languages, as their final grades in high-school for Dutch, English, French, and German are higher than the grades of their counterparts. 
The data also show that ELS graduates do not regret their choice of study. Looking back, $92 \%$ would choose the same study at the same university again, whereas $8 \%$ would choose the same study, but at a different university. This means that European Law School students are more satisfied with their studies than other students, as I8\% of university graduates in general regret their choice of study. If students do drop out, they do so significantly more in the first eighteen months of their study that their counterparts.

\section{Labour Market Position}

The labour market position of students of the English Language Bachelor European Law School is examined by describing several aspects of the current situation and future developments on the labour market. As most bachelor students do not enter the labour market, but continue their educational career by choosing a master programme, the focus here is on labour market outcomes of master degree graduates.

Examining data from the ROA School-leavers Information System (SIS) 1999-2004, we first of all observe that European Law School students more often choose a postgraduate education after graduation than their counterparts in law or other university studies. ELS graduates, thus, invest more in their human capital, and more often postpone their entry on the labour market. When they do start looking for a job, European Law School graduates are more likely to be unemployed for three months or more than their counterparts. However, they eventually succeed in finding a job to the same extent as other university graduates do, as only $6 \%$ is unemployed eighteen months after graduation. They end up in quite attractive job, for ELS graduates are as likely as others to obtain a permanent job. $85 \%$ of them find a job at or above university level, which is far more than graduates from international and European law or non-law university education. On top of that, ELS graduates are more likely to work in their own or related domain than their counterparts from non-law university education. All this implies that there is a market for European Law School graduates. The only disadvantage is that the hourly wages of ELS graduates are slightly lower than those of other university graduates.

European Law School graduates are more likely to find employment as a lawyer (40\%) or a company lawyer (I6\%) than graduates from international and European law, and Dutch Law. Furthermore, they are less spread over different types of occupations. This may indicate the more specific character of European Law School compared to other law studies. The majority of ELS graduates is employed in commercial services, followed by the government. Furthermore, I2\% works abroad eighteen months after graduation, which is far more than their counterparts in international and European law $(5 \%)$ or university graduates in general $(3 \%)$. Thus, the international programme of the European Law School enables students to be really 'international'. 
With respect to the expected developments on the labour market for the next few years, the ROA Labour Market Information System (AIS) on future labour market developments was consulted. This information shows that the demand of graduates of university law studies in general caused by expansion of the labour market grows on an average rate until 20I0. The growth rate is slightly below that for non-law university graduates, though. The demand for law graduates caused by the replacement of employees who leave the labour market (e.g. because of retirement, disability, or temporary withdrawal) can be described as growing on average as well. Combining these two demand factors demonstrates that 13,500 vacancies have to be fulfilled by law graduates in the period 2005-20I0. The growth in the number of job openings as a percentage of employment, however, is somewhat less high for law graduates $(3.0 \%$ per year) than for their counterparts (3.7\% per year).

Labour market predictions were also made for the most prominent occupation European Law School is preparing its students: lawyers (including company lawyers). Again, the growth in expansion demand for lawyers is slightly below the overall growth rate, but it still can be classified as average. The yearly growth in expected replacement of lawyers turns out to be very low. In total, there will be 7,600 job openings for lawyers until 2010. In addition, the data display no expected future bottlenecks in the recruitment for lawyers by employers. Changes in the economic situation are expected to have an average effect on the labour market position of lawyers in the next five years. Furthermore, their alternatives in terms of finding employment in other occupations are expected to be average too.

All in all, the labour market expectations for the period 2005-2010 are somewhat less favourable for law graduates and lawyers than those for non-law university graduates and other occupations. Moreover, there is no sign of future bottlenecks in the recruitment for lawyers by employers. Nevertheless, the number of job openings for law graduates and lawyers is still growing, which makes that European Law School graduates should have sufficient opportunities on the labour market until 2010.

\section{Students' Opinions}

Finally, we consulted students' opinions concerning the new English Language Bachelor European Law School. We conducted group interviews with five different groups of students: bachelor students of the 'classic' European Law School, master students European Law School, bachelor students European Studies, bachelor students of University College Maastricht, and bachelor students Economics.

The interviews show that all five groups of students think that the English Language Bachelor European Law School will provide an interesting alternative, which has the potential to attract more foreign students. However, for the new English Bachelor 
European Law School to be successful, students believe that a couple of crucial conditions have to be met too.

\section{Guarantee of civil effect}

Students of all five groups feel that a civil effect for the English Language Bachelor European Law School is very important. In their opinion, it increases opportunities on the labour market. In addition, students think that most school-leavers do not want to exclude any job options, which makes that the civil effect is quite important when deciding to study European Law School or not. Finally, all students agree that the Faculty of Law should mention in their PR materials what exact requirements need to be met in order to obtain the civil effect.

\section{European law and national law}

Bachelor students of the 'classic' European Law School are enthusiastic about the new track, because courses in European law are offered from scratch. However, they are concerned about studying European law without having a proper base in a national law system. They wonder whether students of the English Language Bachelor European Law School will be able to grasp European law as they do not have a frame of reference. Moreover, students are worried about the limited amount of time spent in the new track on studying a national law system.

\section{First general, then specialized education}

In general, students like broad bachelor programmes, as they do not want to limit their choices too soon. Therefore, ELS students like the present structure of their studies, as it leaves the option open to study Dutch Law after the first year. The new English Language Bachelor European Law School, however, starts with European law from scratch and has no freedom of choice up to the third year. Students are concerned about being too specialized too soon and about the switching possibilities of the new programme. On the other hand, they think that there should be room for specialisation in the third and final year, so the major/minor structure of the new track is very attractive to them.

\section{Challenging Study}

According to the ELS students' opinions, the new English Language Bachelor European Law School should be more demanding than the 'classic' ELS is. The latter study definitely is not the flagship of the Faculty of Law in their opinion. Again, PR materials should be very unambiguous in this respect, as unclear communication only sets wrong expectations, which, in turn decrease students' motivation. Students do not want to introduce selection at the gate, but in order to attract more motivated students, they recommend that new students write a motivational letter. 


\section{Internationalisation}

Students think that teaching all courses in English would definitely attract more foreign students. They believe a mix of 50\% Dutch students and 50\% foreign students to be perfect for an international study environment. However, in order to be a genuine international programme, a study period or internship abroad should be offered. Students indicate that they do not want to wait for their master studies to go abroad. Moreover, the possibility to study across the borders has shown to be a key attraction to new students. Students therefore think it to be a pity that this is not included in the programme of the English Language Bachelor European Law School.

When asked about different ways to recruit new students, most Dutch students mention that they went to one of the open days of the university. They also got advice from student advisors at their high school, and read printed brochures or information on the Internet. Some visited the 'Studie Beurs' in Utrecht. Foreign students, on the other hand, primarily seek information on the Internet. In addition, several German students visited the 'Einsteig Abi Messe' in Cologne. Another important information channel for new students are their friends and relatives who already study at Maastricht University.

Almost all ELS students considered other universities before deciding to study at Maastricht University. Dutch students mainly thought about studying law at other Dutch universities. Foreign students considered studying at their national universities too, but in general look for universities that teach (most of their) courses in English, like universities in the United Kingdom. Other studies considered included International Business, University College Maastricht, and European Studies. However, these studies do not provide a civil effect in law.

Students came up with a long list of attractive features of Maastricht University that could be used in recruitment:

- Problem Based Learning system: small groups, more motivated students, teaches interpersonal and problem solving skills;

- Small scale university: familial atmosphere, good student-staff relations;

- International atmosphere: students from different national backgrounds, English language courses;

- Excellent student facilities: library, computers and internet access, student life;

- Easy admission: no entry exams or numurus clauses, low tuition fees;

- City of Maastricht: small, neatly organized, close proximity to Germany and Belgium.

Interestingly, students found it much more difficult to think about negative features of Maastricht University. One minor aspect that was mentioned is the bureaucracy at the university. Especially for foreign students, it takes a while before everything is 
arranged and students don't find student services or the 'Onderwijsbalie' very helpful. Foreign students think that housing is quite expensive, and German and Belgian students complain about the parking policy.

Finally, we asked students about their expectations of their future labour market position. First and foremost, all students want to continue their academic careers by following a master programme. Most bachelor ELS students intend to choose the European Law School Master, but some will switch to the Dutch Law Master, as this - in their opinion - gives them more opportunities on the labour market. Almost all ELS students want to stay in Maastricht for their master, because they are familiar with the educational system and have strong social ties in Maastricht.

After graduation, about half of the ELS students interviewed would like to work abroad, for example in a large company, or in an EU institution. The majority of students, however, believe that they need work experience in their national law system first, before being able to find a job abroad. Therefore, the civil effect is very important to them. Most European Law School students want to become company lawyers, whereas some think about working in the so-called 'togaberoepen' (lawyer or judge). The majority of European Law School students think that their degree will make it possible to work not only in (European) law, but in various related fields as well. Moreover, they are fully confident that they will find an interesting job after graduation. 


\section{Introduction}

\subsection{Background}

Maastricht University is progressively attracting more foreign students. The annual report of 2004 shows that almost $40 \%$ of the intake of new, regular students originates

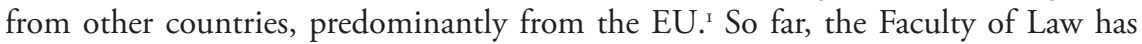
been contributing to the ambition of Maastricht University to increase this intake of foreign students by offering English language masters and the post-graduate MIC programme. However, at the bachelor level, the Faculty of Law is also seeking new ways to increase the intake of students from abroad. In order to attract more foreign students earlier on in the curriculum, the Faculty of Law wants to initiate an English language bachelor programme for the European Law School (EELS) alongside the 'classic' bachelor European Law School (ELS).

This 'classic' bachelor European Law School can be described as a double track of Dutch law and European and comparative law. It starts off with a propaedeutic year that is completely similar to Dutch Law, which implies that the first year of the ELS programme is offered in Dutch and that enrolment is practically limited to Dutch speakers. At the end of this first year, students continue with European Law School or choose the bachelor Dutch Law. Dutch Law offers students a thorough insight in criminal law, private law, company and business law, and constitutional and administrative law. The 'classic' European Law School, on the other hand, teaches European Law in a comparative way from the second year onwards, in addition to teaching the Dutch law system. Table I.I shows that Dutch Law attracts for more students than European Law School. However, the number of bachelor ELS students is growing by $3 \mathrm{I} \%$ over the past four years, whereas the number of bachelor students Dutch Law is declining by $25 \%$.

So far, Maastricht University is the only university in the Netherlands offering such an bachelor ELS programme. There are some international law programmes or courses that students can take at other Dutch universities, but these do not provide a general comparative law system in the way the European Law School does. Competition also

I. Universiteit Maastricht (2005). Jaarverslag 2004. Maastricht. 
comes from abroad, in particular from universities in England, as they offer English language courses and have a high prestige. Their base, however, is in English Law.

Table 1.1

Intake of bachelor students

\begin{tabular}{lccccc} 
& \multicolumn{4}{c}{ Number of students } & \multicolumn{2}{c}{ Growth } \\
& $2002-2003$ & $2003-2004$ & $2004-2005$ & $2005-2006$ & $\%$ \\
European Law School & 94 & 116 & 148 & 124 & 31 \\
Dutch Law & 259 & 284 & 240 & 195 & -25
\end{tabular}

Source: Faculty of Law

Enabling foreign students to enrol in the bachelor European Law School, which in the first year predominantly teaches Dutch law in the Dutch language, requires increasing the amount of courses taught in English. This has spurred the Faculty of Law of Maastricht University to investigate the possibility to establish a new variant or track of the 'classic' ELS bachelor programme. The University wants to offer an English Language Bachelor European Law School which allows students to study European law as a major and several national law systems (e.g. Belgian law, German law, or Dutch law) as minors. At the moment, non-Dutch speaking students already have the possibility of doing an English Language Master European Law School at Maastricht University, but so far there was no room to do an English Language Bachelor European Law School.

This new English language bachelor programme within the Faculty of Law will consist of a broad 3-year programme. The common basic introductory year of the 'classic' ELS will be replaced with a full English language education programme from scrap. In essence, this will result in the removal of Dutch law from the basic bachelor curriculum. Instead, an introduction to law will be offered along the lines of universal legal principles, Ius Commune, harmonised law, and comparative study. To be more specific, year one of the English Language Bachelor European Law School is intended to teach introduction to law, comparative contract law, comparative constitutional law, legal English, legal history, common law, comparative private law, and comparative criminal law. Year two covers International law and European law, European law foundations, legal writing, private international law, European law: substantive, European company law, European contract law, states, markets \& European integration, and moot court training. Finally, year three of EELS comprises elective subtracks; e.g. German law, Belgian law, or Dutch law. These minors are necessary in order to obtain a civil effect in German, Belgian, or Dutch law. ${ }^{2}$

At the moment, students of the 'classic' bachelor ELS have the possibility to continue their law education at Maastricht University in two 'doorstroom' masters for which no additional requirements are mandatory, i.e. European Law School Master and Dutch Law Master. Both masters are one-year programmes. The European Law

2. In order to obtain a civil effect, students will have to follow a master programme in German, Belgian, or Dutch Law as well. 
School Master is taught entirely in English, whereas courses in the Dutch Law Master are mainly offered in Dutch. In addition, students of ELS may choose one of the other UM law masters, e.g. Globalisation and Law (one-year programme), Law and Language Studies (two-year programme with a six-month period spent abroad), and Ius Commune and Human Rights Research (two-year research master). These masters are taught in English, but ELS graduates need additional requirements to enter these master programmes. ${ }^{3}$ At the moment, these law masters are already attracting foreign students. Table I. 2 shows that more than half of the European Law School master students come from abroad. The new English Language Bachelor European Law School also intends to equip its students with the right body of knowledge to continue their academic career at Maastricht University, in particular by doing the English Language Master European Law School.

Table 1.2

Intake of master students

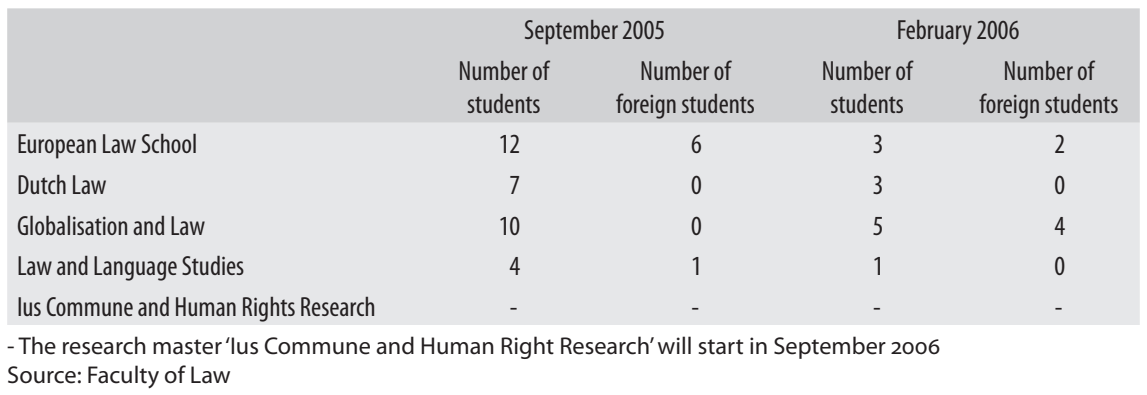

As Maastricht University wants to attract more students, in particular more students from abroad, it wants to assure that foreign students commit themselves to the university as early as possible. Students following a bachelor programme may continue their academic career choosing for a master programme after graduation. Therefore, the enrolment of foreign students in bachelor programmes may generate higher enrolment rates for the master studies. Universities hold the expectation that only a minority of students make the immediate transition into the labour market after successfully completing the bachelor degree. The vast majority ( $84 \%)$ is expected to continue their academic education doing a master programme. ${ }^{4}$

For an English Language Bachelor European Law School to be a success, the Faculty of Law emphasizes that the following factors should be taken into account:

- EELS should be a track within the 'classic' European Law School in order to enable foreign students to follow the same English language courses their Dutch colleagues take.

3. Student Services Universiteit Maastricht (2004). Masters in Maastricht 2005. Maastricht.

4. Inspectie van het Onderwijs (2003). BAMA-Transities. De invoering van het Bachelor-Masterstelsel in het WO en HBO. Utrecht. 
- Staff and capacity must be equipped to face the challenges of receiving foreign students at a much earlier stage in the curriculum, and in larger numbers.

- A coherent curriculum with a focus on European and comparative law should be developed, ensuring the quality of the overall curriculum, as opposed to offering the civil effect.

- Minor tracks in not only Dutch law but also in Belgian or German law should be offered to enhance the attraction of EELS.

- EELS should appeal to the internationally oriented student and its programme should primarily enable the student to have access to English master programmes at the Faculty of Law at Maastricht University or elsewhere.

In general, the Faculty of Law thinks that the English Language Bachelor European Law School is feasible when a number of five regular students enrol. There will be no entrance exam or other type of selection at the gate, as Dutch law does not allow this. However, EELS students will receive a Binding Study Advice (BSA) before the end of the first year. They will not be allowed to continue their studies if they received less than 30 ECTS credits at the end of the first year or if they do not successfully complete all units of the first-year programme after two years. A Binding Studying Advice is given to all students at the Faculty of Law and serves as a selection mechanism.

\subsection{This Report}

The Research Centre for Education and the Labour Market (ROA) was asked by the Faculty of Law to examine whether the expectations concerning the English Language Bachelor European Law School are feasible. The research in this report builds on two pillars: recruitment and labour market position.

In order to analyze the recruitment power of the English Language Bachelor European Law School, we will examine which students actually choose to do European Law School. Their profile consists of several components: gender, age, type of pre-university education, regional background, nationality, and subjects (languages) chosen at pre-university education. We will also show information about dropouts and whether graduates regretted their choice of university education. The results on recruitment power can be found in chapter two of this report.

Second, we will consider to what extent the English Language Bachelor European Law School is fulfilling an obvious economic and social need. In order to study the feasibility of this new track, we will address several aspects of the current situation and future developments on the labour market. As mentioned before, most bachelor students do not enter the labour market, but continue their educational career by choosing a master programme. In order to scrutinize potential bachelors' labour market position we therefore need to focus our attention on the labour market outcomes of master degree graduates. We will subsequently examine the enrolment in postgraduate educa- 
tion; graduates' labour market position in terms of job characteristics; the school-towork transition with respect to unemployment spells and the match between study followed and present job; and occupations, branches, and regions where graduates find their jobs. We will present this information in chapter three of this report and conclude with a description of the expected developments on the labour market for the next five years.

The sources underpinning these two chapters of our report are diverse of character. The major part of our data is derived from the ROA School-leavers Information System (SIS) I999-2004.5 Each year, school-leavers of all educational types are asked to fill out a questionnaire eighteen months after graduation. We will display information on graduates from pre-university education (VWO) and on university graduates (WO). Response rates on average are around $60 \%$ and $48 \%$ respectively. Note that we focus our attention on fulltime graduates. As mentioned before, most bachelor students will continue their academic career by doing a master programme instead of entering the labour market. Therefore, we focus our description of the labour market position on graduates with an undergraduate degree (drs. or mr. title), which is the 'old' equivalent of a master degree. ${ }^{6}$

Throughout this report, we will compare four groups of university studies on their students' profile - recruitment power - and labour market position:

- European Law School (ELS);

- International and European law;

- Other law education, primarily Dutch law;

- Other, non-law, university education.

We explicitly distinguish between European Law School and international and European law, as the latter can be seen as the most direct competitor of ELS in the Netherlands. An overview of the underlying university studies in each group can be found in Appendix A. Table I.3 shows for each group the number of university graduates that participated in the SIS survey in the period 1999-2004. About I2\% of the graduates has a law degree, of which 0.I\% a degree in European Law School and 0.4\% a degree in international and European law.

Apart from employing the survey information mentioned, we also consulted the ROA Project Education/Labour Market (POA) information system, which entails information on present and future labour market developments for type of education, occupation, and sector of industry. ${ }^{7}$

5. See for a description of SIS e.g. ROA (2005). Schoolverlaters tussen onderwijs en arbeidsmarkt 2004. ROA-R-2005/6. Maastricht.

6. The Bachelor-Master (BaMa) system was implemented at Dutch universities in 2002-2003.

7. See also ROA (2005). De arbeidsmarkt naar opleiding en beroep tot 20I0. ROA-R-2005/9. Maastricht. 
Table 1.3

Number of graduates participating in SIS survey

\begin{tabular}{|c|c|c|}
\hline & $\begin{array}{r}\text { Number of } \\
\text { students }\end{array}$ & $\%$ \\
\hline European Law School & 64 & 0.1 \\
\hline International and European law & 205 & 0.4 \\
\hline Dutch law & 6,070 & 11.5 \\
\hline Non-law university education & 46,547 & 88.0 \\
\hline University education total & 52,886 & 100.0 \\
\hline
\end{tabular}

Source: SIS 1999-2004

In addition to this quantitative information, we consulted students' opinion concerning the new English Language Bachelor European Law School. We conducted group interviews with five different groups of students: bachelor students of the 'classic' European Law School, master students European Law School, bachelor students European Studies, bachelor students of University College Maastricht, and bachelor students Economics. Students were asked to express their opinion about the new English Language Bachelor European Law School, their study and Maastricht University, recruitment, and their labour market position. They were also asked to fill in a short questionnaire with open-ended questions on these topics. The results obtained through these group interviews are described in chapter four of this report. 


\section{Recruitment}

\subsection{Introduction}

In order to determine the recruitment power of the English Language Bachelor European Law School, in this chapter, we will investigate what type of students have chosen to do European Law School, for the academic years 1999/2000 up to and including 2004/2005. ${ }^{\mathrm{I}}$ Examining graduates from these academic years, we will describe several components of their 'profile'. First, we will illustrate the background characteristics of ELS graduates. These features constitute gender, age, and education prior to going to university. Second, we will analyse the students' region of origin and nationality in order to consider whether the current European Law School already attracts some international students. In addition, the languages studied at pre-university education will be analysed, as European Law School embodies an international programme. We will answer the question whether ELS students scored higher on language grades at pre-university education than their counterparts. Finally, the match between pre-university education and study followed is considered. Do students hold any regret concerning their choice of study, and how high is the dropout rate?

We will use this profile of students as a proxy for the potential intake of the new English Language Bachelor European Law School. Throughout this and the next chapter we will highlight our main findings using the four categories of university graduates explained in the first chapter: European Law School, international and European law, Dutch law, and non-law university education. Note that while describing the differences between groups of graduates, we will only discuss statistically significant differences.

\subsection{Background Characteristics}

In order to establish the recruitment power of students for the new track, we analyzed some personal characteristics of graduates in order to construct a 'profile' of potential English Language Bachelor European Law School students. Comparing the group

I. Note that these European Law School graduates followed the old curriculum (doctoraal ELS). The new equivalent, the European Law School Master, just started this academic year, 2005/2006. 
of European Law School graduates with the other three academic categories, we will highlight some findings with respect to gender, age, and prior education.

For all four different categories of university studies, Figure 2.I illustrates the percentage or share of women. Our findings show that this percentage does not significantly differ among European Law School compared to the other three categories. In other words, ELS cannot be labelled to be a typical 'feminine' study, as gender effects do not play a distinguishing role. We do, however, observe that women constitute the majority of European Law School students (60\%), which is in line with the overall trend at university education.

\section{Figure 2.1}

Percentage of female students

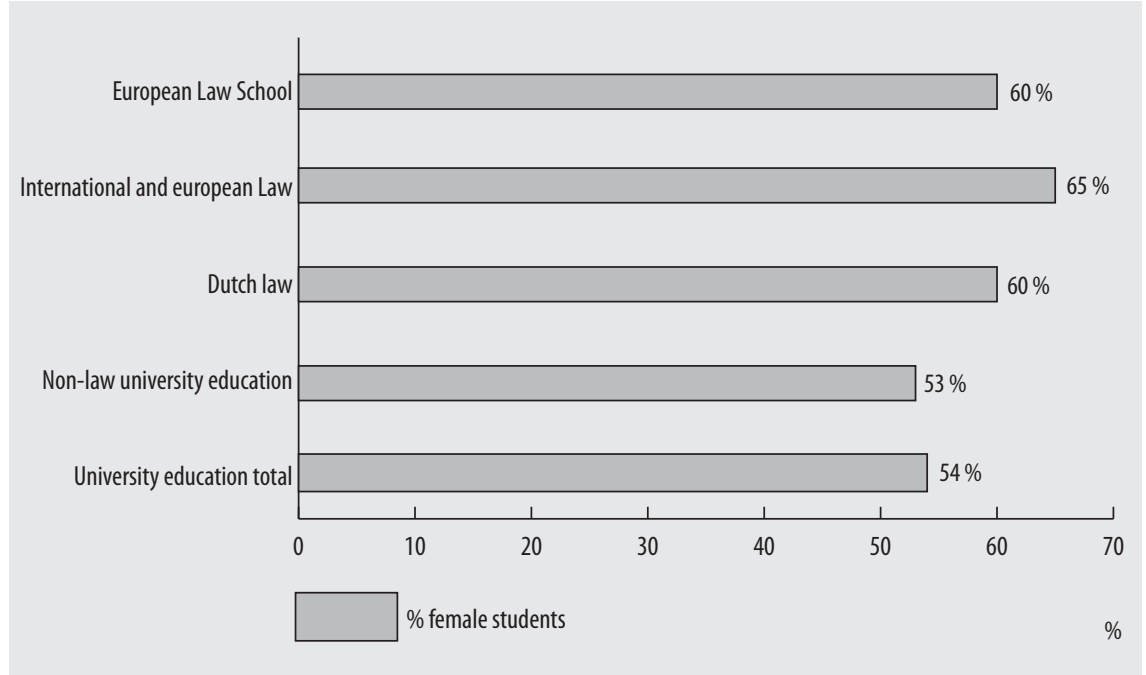

Source: SIS 1999-2004

In addition, we derive from Table 2.I that graduates from European Law School are significantly younger than students from international and European law, Dutch law, as well as non-law university education. ELS students, thus, complete their studies at a faster rate than their counterparts graduating from other university studies. This may imply two things. On the one hand, it could result from the fact that their study duration is less long than others, which, in turn, may indicate that European Law School is 'less demanding' in terms of content than for instance Dutch law, where students are on average older when graduating. This contradicts the Faculty of Law's believe that European Law School should be the 'flagship' of the Faculty. On the other hand, this result could also be generated by the fact that ELS students have a different education background in terms of prior education, as will be explained below. 
Table 2.1

Average age at graduation

$\begin{array}{lc}\text { European Law School } & \begin{array}{c}\text { Average age at } \\ \text { graduation } \\ \text { in years }\end{array} \\ \text { International and European law } & 23,2 \\ \text { Dutch law } & 24,8 \\ \text { Non-law university education } & 25,5 \\ \text { University education total } & 25,4\end{array}$

Source: SIS 1999-2004

In Table 2.2, we present an overview of prior education before entering university. The figures indicate that pre-university education in most cases prepares students for enrolment in either one of the four academic categories. In addition, Higher Vocational Education (HBO) is an important stepping-stone for entering either Dutch law or non-law university education, but not for European Law School or international and European law. To come back to the aforementioned age differences of graduates, European Law School students might have a younger age at graduation, because they are more likely to come from pre-university education. The older average age of Dutch law students on the other hand may result from first enrolment in Higher Vocational Education (HBO) before entering academic education.

Table 2.2

Prior education before entering university

\begin{tabular}{|c|c|c|c|c|c|}
\hline & $\begin{array}{l}\text { Higher General } \\
\text { Secondary } \\
\text { Education } \\
\text { (HAVO) }\end{array}$ & $\begin{array}{l}\text { Pre-universiity } \\
\text { Education } \\
\text { (VW0) }\end{array}$ & $\begin{array}{l}\text { Higher Vocational } \\
\text { Education } \\
\text { (HBO) }\end{array}$ & $\begin{array}{l}\text { University } \\
\text { Education } \\
\text { (W0) }\end{array}$ & Other \\
\hline & $\%$ & $\%$ & $\%$ & $\%$ & $\%$ \\
\hline European Law School & 2 & 76 & 5 & 2 & 15 \\
\hline International and European law & 1 & 82 & 5 & 10 & 2 \\
\hline Dutch law & 2 & 79 & 10 & 6 & 2 \\
\hline Non-law university education & 1 & 78 & 16 & 3 & 2 \\
\hline University education total & 1 & 78 & 15 & 4 & 2 \\
\hline
\end{tabular}

Source: SIS 1999-2004

\subsection{Region and Nationality}

Becoming an international university in terms of attracting large numbers of foreign students does not happen overnight; it takes time to adapt the university's programme and to recruit students from abroad. As the Faculty of Law of Maastricht University aims to attract more foreign students with the introduction of the new English 
Language Bachelor European Law School, we are interested whether the current European Law School already represents an international mixture of students. In addition, we consider which nationalities enrol in ELS, since this can help in the recruitment process of luring additional foreign students to come to Maastricht University. It may provide valuable insights on which nationalities the university could focus its attention.

Our findings in Figure 2.2 display that students of the 'classic' European Law School are more often born abroad than their counterparts. The share of foreign students, in terms of country of origin, is rather high for ELS (30\%) in comparison to international and European law (II\%), and the rest (6\%). Additionally, Table 2.3 shows that these foreign enrolled students are primarily coming from Belgium; they constitute I $4 \%$ of the total European Law School student population. Because flemish students speak Dutch, they have no problems enrolling in the 'classic' European Law School. Only a few ELS students (2\%) were born in Germany. This may indicate that the German market may embody a potential grow market, considering the Faculty of Economics and Business Administration's intake of German students.

\section{Figure 2.2}

Percentage of graduates born abroad

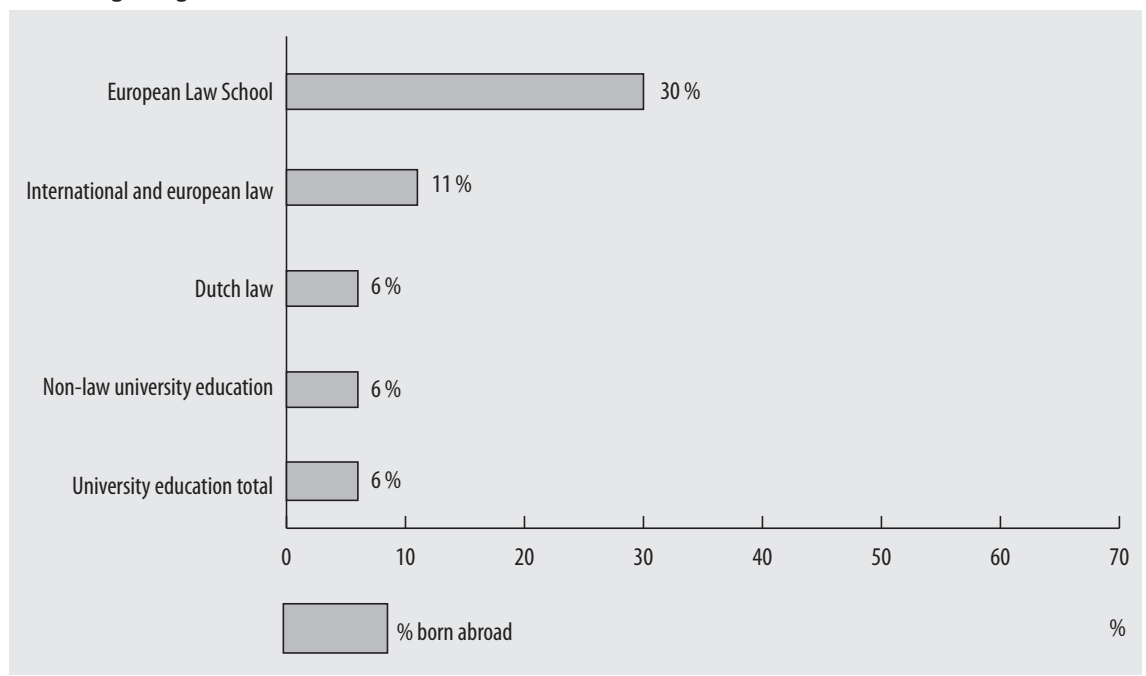

Source: SIS 1999-2004

However, one potential pitfall immediately emerges, as comparing law and economics is like comparing apples and oranges. 'Law' clearly does not resemble 'economics', simply because economics' natural language is English, while law's natural language is conditional upon the national legal system in which it is embedded (e.g. Dutch law is taught in Dutch and German law in German). Consequently, not all law studies are suitable for an international English language programme. The new English Language 
Bachelor European Law School, however, certainly is a study that lends itself to be taught in English, because of its hybrid structure. Its major comprises European and comparative law, while its minors offer room to specialize in three national legal systems, e.g. Dutch law, Belgian law, or German law.

Table 2.3

Country of birth of European Law School graduates

$\begin{array}{lc}\text { Country of birth } & \% \\ \text { The Netherlands } & 70 \\ \text { Belgium } & 14 \\ \text { Germany } & 2 \\ \text { France } & 2 \\ \text { Italy } & 2 \\ \text { Poland } & 2 \\ \text { Russia } & 2 \\ \text { United States } & 2 \\ \text { Egypt } & 2 \\ \text { South-Korea } & 2 \\ \text { Taiwan } & 2 \\ \text { Total } & 100 \\ \text { Source: SIS 1999-2004 } & 2\end{array}$

On top of analyzing foreign intake, we examined the (regional) attractiveness of the four categories of academic education by considering both study's location and student's region of residence. ${ }^{2}$ Note that the European Law School is only offered at Maastricht University, whereas international and European law, Dutch law, and nonlaw university education are offered in all regions in the Netherlands.

Figure 2.3 shows that students choosing European Law School Master are less likely to come from the West of the Netherlands than is the case for Dutch law and nonlaw university education, while they are more likely to come from the South of the Netherlands. This means that European Law School attracts quite a lot of students from its own region. This is quite remarkable, given the fact that European law can only be studied in a comparative way in Maastricht.

In general, we found that student's region of residence and study's location are strongly correlated, which acknowledges the general trend in the Netherlands that students vote with their feet. Students from the South choose to study at a university in the South, whereas students from the West remain in the West.

2. Student's region of residence is based on the address last known by the university of enrolment. Although many changes might happen during the period of enrolment, this measure is the best proxy we have of student's region of residence. Moreover, it may offer valuable insights on how far students had to travel to follow classes. 
Figure 2.3

Percentage of graduates originating from the North, South, East, and West
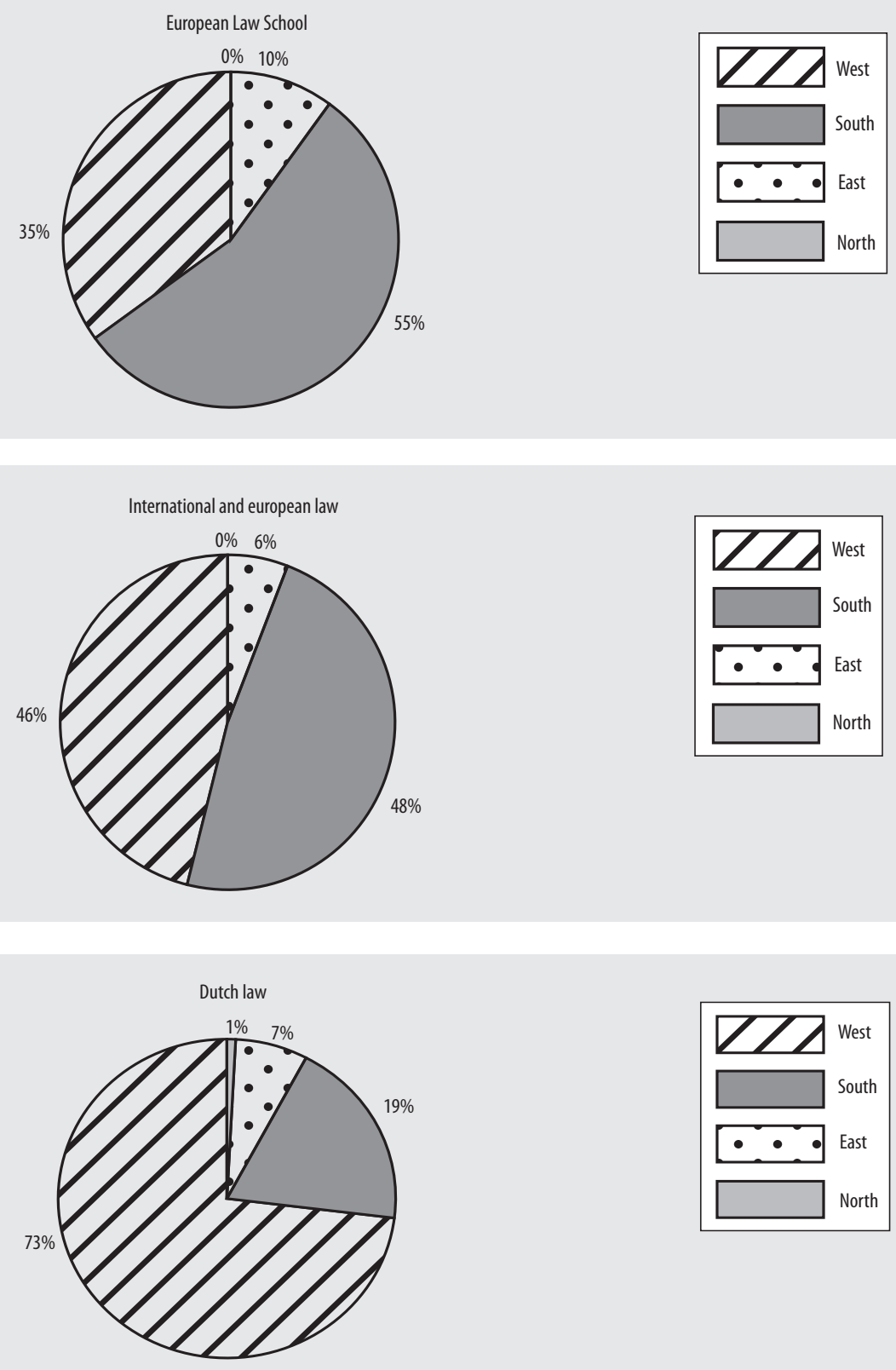
Figure 2.3 (continued)

Percentage of graduates originating from the North, South, East, and West
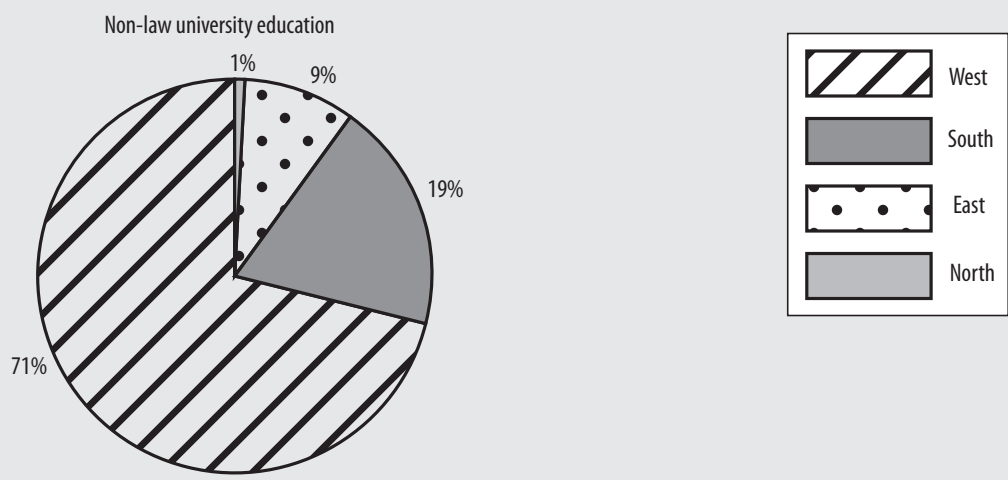

University education total
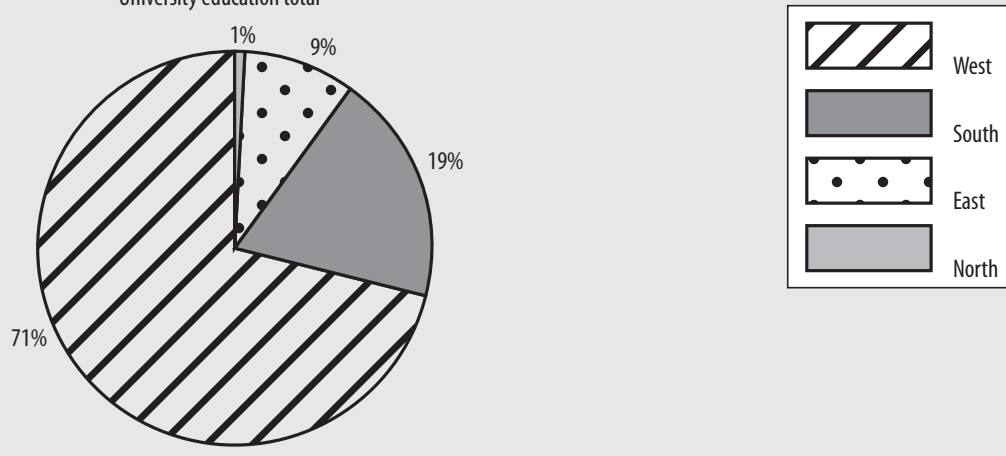

Source: SIS 1999-2004

\subsection{Languages}

As European Law School is designed to be a fairly international programme, students require a certain level of expertise in foreign languages in order to successfully complete their studies. Courses are offered in Dutch and in English, which means that students need to have a thorough and active knowledge of these languages. However, passive knowledge of German and French languages is required as well, as examination and education may comprise German and French literature. ${ }^{3}$ In addition, the new English Language Bachelor European Law School offers specialization in minors in terms of a national legal system (e.g. Dutch law, Belgian law, or German law). This specialization also requires a high level of expertise of these languages. Therefore, we considered the

3. Website of the Faculty of Law at www.unimaas.nl. 
average final examination grades scored for several languages (i.e. Dutch, English, German, and French) being taught at pre-university education. ${ }^{4}$ Our findings suggest that students choosing European Law School indeed are 'better' in terms of languages, in particular, in comparison with students studying non-law university education. This implies that ELS probably attracts the more internally oriented students.

\subsection{Regret and Dropouts}

Students' possible regret of the choice of study when looking back after graduation, may also point towards a study programme's attractiveness. Table 2.4 shows that graduated students from European Law School are more likely to stand by their choice of study than others. Looking back, $92 \%$ would choose the same study at the same university again, whereas $8 \%$ would choose the same study, but at a different university. This implies that ELS graduates would not choose a different study, which is quite remarkable, as in general, $\mathrm{I} 8 \%$ of university graduates regret their choice of study. In other words, students graduating from the European Law School are significantly 'more satisfied' with the study followed than their counterparts. This suggests that European Law School offers students a good 'deal' in terms of academic skills and knowledge for the labour market.

On top of that, we analyzed the 'dropout' rate for the four university categories. We examined whether pre-university education graduates enrolling in European Law School, international and European law, Dutch law, or non-law university education brought their studies to an end within eighteen months after graduating from VWO.5 It seems that European Law School students are somewhat more likely to drop out than students from international and European law, and Dutch law. This implies that ELS students who do not like their studies, drop out fairly early in the bachelor phase.

Table 2.4

Graduates' choice of study looking back after graduation

$\begin{array}{lcccc} & \begin{array}{c}\text { Same study, at same } \\ \text { university }\end{array} & \begin{array}{c}\text { Same study, at } \\ \text { different university }\end{array} & \text { Different study } & \text { Not study } \\ \text { European Law School } & \% & \% & \% & \% \\ \text { International and European law } & 92 & 8 & 0 & 0 \\ \text { Dutch law } & 71 & 8 & 21 & 0 \\ \text { Non-law university education } & 77 & 10 & 13 & 0 \\ \text { University eductation total } & 72 & 8 & 19 & 1\end{array}$

Source: SIS 1999-2004

4. Because of the low number of respondents answering these questions in the SIS survey, we are not able to present the exact average final examination grades for students of the four university categories.

5. Because of the low number of respondents answering these questions in the SIS survey, we could not present the exact dropout rate for students of the four university categories. 


\section{Labour Market Position}

\subsection{Introduction}

In this chapter, we will illustrate the present and future labour market position of graduates from the English Language Bachelor European Law School. We will present this illustration on the basis of the School-leaver Information System (SIS) survey of university graduates leaving university in the period 1999-2004. Questionnaires were sent to students of all thirteen universities in the Netherlands, eighteen months after graduation. It, therefore, considers graduates' labour market situation at the beginning of their professional careers. With this information on graduates of the 'classic' European Law School, we want to construct a picture on the societal and economical needs for graduates from the English Language Bachelor European Law School. We will describe to what extent graduates continue doing a postgraduate, their probability of attaining a job, and their labour market position in terms of working hours per week, wages earned, and having a permanent job. We will also consider the transition into the labour market with respect to the match between study followed and the present job. In addition, we will present an overview of the kind of jobs and branches in which European Law School graduates are employed. We will conclude this chapter with a description of the expected developments on the labour market, based on data from ROA's Project Education/Labour Market information system (POA).

\subsection{Postgraduate Education}

Not all graduates immediately enter the labour market after leaving university. Some university graduates decide to continue investing in their human capital in order to increase the market value of their productive capacity at the labour market. These graduates often choose for a postgraduate education. Table 3.I presents an overview of the percentage of graduates that continues studying by doing a postgraduate.

The figures clearly show that the majority of university graduates do not choose a postgraduate, but enter the labour market (72\%). Graduates of European Law School, however, invest much more in their human capital by doing some sort of postgraduate: $3 \%$ becomes a Ph.D. student, $17 \%$ is involved in a combination of postgraduate 
education together with a job, and 31\% follows another form of postgraduate education. This is quite remarkable, as law graduates, in general, are less likely to do a postgraduate (and, in particular, a Ph.D.) after completing university than other graduates. They however, are, more likely to be involved in a combination of postgraduate education and a job. This may suggest that law studies equip their students with more practical applicable skills, in contrast to other non-law university education. All in all, the figures show that many European Law School graduates postpone their entry on the labour market by following a postgraduate.

Table 3.1

Postgraduate education of graduates

$\begin{array}{lcccc} & \text { PhD } & \begin{array}{c}\text { Combination } \\ \text { Postgraduate/Job }\end{array} & \begin{array}{c}\text { Other } \\ \text { Postgraduate }\end{array} & \begin{array}{c}\text { No } \\ \text { Postgraduate }\end{array} \\ \text { European Law School } & \% & \% & \% & 49 \\ \text { International and European law } & 3 & 17 & 31 & 79 \\ \text { Dutch law } & 2 & 15 & 7 & 73 \\ \text { Non-law university education } & 2 & 13 & 12 & 71 \\ \text { University education total } & 10 & 7 & 12 & 72\end{array}$

Source: SIS 1999-2004

\subsection{Labour Market Position}

When entering the labour market, do European Law School graduates find a job quickly? If so, this may indicate that this study is fulfilling a societal and/or economical need. The first column of Table 3.2 presents the percentage of graduates that belong to the unemployed labour force. The figures display that $4 \%$ of all graduates are unemployed eighteen months after graduation. Although the figures are slightly worse for European Law School - 6\% is unemployed - graduates from ELS are not more likely to end up in the unemployed labour force than their counterparts from Dutch law or non-law university education. In comparison to international and European law, ELS graduates however are slightly more likely to be part of the unemployed labour force eighteen months after graduation.

The second column of Table 3.2 shows that, in terms of being unemployed for three months or more after graduation, the differences between the four university categories are more severe. The table shows that graduates from European Law School are more likely to be unemployed for three months or more in the eighteen months after graduation (2I\%) than graduates from international and European law (I4\%), Dutch law (II\%), as well as graduates from non-law university education (I3\%). This means that European Law School graduates have somewhat more problems finding a job, but eventually succeed in this to the same extent as other university graduates do. 
Table 3.2

Unemployment of graduates

$\begin{array}{lcc} & \begin{array}{c}\text { Unemployed Labour } \\ \text { Fonths or more } \\ \text { European Law School }\end{array} & \begin{array}{c}\text { Mnemployed } \\ \%\end{array} \\ \text { International and European law } & 6 & 21 \\ \text { Dutch law } & 2 & 14 \\ \text { Non-law university education } & 3 & 11 \\ & 4 & 13 \\ \text { University education total } & & 13\end{array}$

Source: SIS 1999-2004

As the vast majority of graduates from European Law School generally find jobs, how attractive are these jobs? Table 3.3 presents some job characteristics of working graduates: number of working hours, gross hourly wage, and having a permanent job.

Table 3.3

Labour market position of graduates

$\begin{array}{lccc} & \text { Hours of work } & \text { Gross hourly wage } & \text { Permanent job } \\ & \text { per week } & € & \% \\ \text { European Law School } & 38 & 12,10 & 32 \\ \text { International and European law } & 37 & 13,30 & 51 \\ \text { Dutch law } & 38 & 13,40 & 49 \\ \text { Non-law university education } & 36 & 13,40 & 43 \\ \text { University education total } & & & 43\end{array}$

Source: SIS 1999-2004

The figures show that graduates from European Law School work more hours per week, but earn less per hour than graduates from non-law university education. Also in comparison to graduates from international and European law and Dutch law, they earn less per hour. This suggests that ELS graduates end up in less attractive jobs than their counterparts. However, they are as likely as the others to obtain a permanent job.

\subsection{Match between Study Followed and Present Job}

The match between study followed and present job can be seen as an indicator of both the extent to which a market for graduates of a specific study exists, as well as the quality (i.e. level) of the work that graduates found. Two aspects of this match can be disentangled: a vertical match between the level of education required in the present job and the level of education followed and a horizontal match between the field of study required in the present job and the field of study followed. Table 3.4 illustrates these two school-to-work transition indicators. 
Table 3.4

Match between study followed and present job

$\begin{array}{lcc} & \text { Job at university level } & \text { Job in own/related field } \\ & \% & \% \\ \text { European Law School } & 86 & 81 \\ \text { International and European law } & 67 & 77 \\ \text { Dutch law } & 76 & 78 \\ \text { Non-law university education } & 59 & 68 \\ \text { University education total } & & 69\end{array}$

Source: SIS 1999-2004

We find that graduates from European Law School are more likely to work at or above university level (86\%) than both international and European law (67\%), and non-law university education (59\%). This first of all implies that the vast majority of ELS graduates find a job that (vertically) matches their university education. On top of that, graduates from European Law School are more likely to work in their own or related domain than their counterparts from non-law university education. Thus, ELS graduates also find jobs that horizontally match their academic studies. All this implies that there is a market for European Law School graduates. ${ }^{1}$

\subsection{Occupations and Branches: in The Netherlands or Abroad?}

In which occupations and branches do European Law School graduates work? Tables 3.5 and 3.6 present an overview of the occupations and branches in which graduates from all law studies found employment. Table 3.5 suggests that graduates from European Law School are more likely to find employment as a lawyer (40\%) or a company lawyer (I6\%) than graduates from international and European law, and Dutch law. Furthermore, they are less spread over different types of occupations. This may indicate the more specific character of the European Law School compared to the other two law categories.

Table 3.6 displays an overview of the branches in which graduates from law studies are employed. It shows that graduates from European Law School as well as Dutch law mainly find employment in the commercial services, followed by government, whereas the order for graduates from international and European law is the other way around. Commercial services and government together employ the majority of law graduates. Besides in those two branches, graduates from law studies also work in education, insurance, and banking.

I. Please note that the European Law School graduates in the survey graduated with a civil effect in Dutch law. 
Table 3.5

Occupations in which law graduates are employed

$\begin{array}{lr} & \% \\ \text { European Law School } & 40 \\ \text { Lawyer } & 16 \\ \text { Company lawyer } & 8 \\ \text { Teacher (1st grade and university) } & 36 \\ \text { Other } & 21 \\ \text { International and European law } & 12 \\ \text { Lawyer } & 9 \\ \text { Lawyer/notary } & 7 \\ \text { Policy official } & 6 \\ \text { Company lawyer } & 45 \\ \text { Juristic advisor } & \\ \text { Other } & 21 \\ \text { Dutch law } & 9 \\ \text { Lawyer } & 9 \\ \text { Tax consultant } & 8 \\ \text { Company lawyer } & 7 \\ \text { Lawyer/notary } & 7 \\ \text { Juristic advisor } & \\ \text { Other } & 46\end{array}$

Source: SIS 1999-2004

Table 3.6

Branches in which law graduates are employed

$\begin{array}{lr} & \% \\ \text { European Law School } & 51 \\ \text { Commercial services } & 24 \\ \text { Government } & 14 \\ \text { Education } & 11 \\ \text { Other } & \\ & \\ \text { International and European law } & 41 \\ \text { Government } & 33 \\ \text { Commercial services } & 7 \\ \text { Education } & 5 \\ \text { Other services } & 14 \\ \text { Other } & \\ \text { Dutch law } & \\ \text { Commercial services } & 53 \\ \text { Government } & 26 \\ \text { Insurance } & 4 \\ \text { Banking } & 4 \\ \text { Education } & 4 \\ \text { Other } & 4 \\ \text { Source: SIS } & 9\end{array}$

Source: SIS 1999-2004

In addition to the question in which jobs or branches graduates find employment, we are also interested in the question whether they do so abroad or in the Netherlands. 
In Table 3.7, we analyze the division of working graduates over the Netherlands and abroad. The figures suggest that graduates from European Law School indeed face better odds to go abroad (I2\%) than other university education graduates in general (3\%). Even their counterparts who studied international and European law less often work abroad (5\%). This acknowledges the believe that the international programme of the European Law School enables students to be really 'international'.

\section{Table 3.7}

Employment abroad of graduates

\begin{tabular}{lc} 
& Work abroad \\
European Law School & $\%$ \\
International and European law & 12 \\
Dutch law & 5 \\
Non-aw university education & 2 \\
University education total & 4 \\
\hline
\end{tabular}

Source: SIS 1999-2004

\subsection{Expected Developments on the Labour Market}

Finally, we will illustrate the expected labour market developments for European Law School graduates on the middle-long run. The presented labour market perspectives embody predictions in terms of demand and supply conditions on the labour market until 20IO. Due to data restrictions, the expectations could not be specified for European Law School alone. Instead, we considered law studies in general to proxy our predictions for ELS. We will first look at the expected demand for university graduates. This demand for newcomers consists of two aspects: the demand caused by employment growth (so-called expansion demand), and the demand caused by the replacement of employees who leave the labour market, e.g. because of retirement, disability, or temporary withdrawal from the labour market (replacement demand).

Table 3.8

Expansion demand for university graduates, 2005-2010

$\begin{array}{lccc} & \text { Expansion demand } & \text { Yearly } & \text { Characterisation } \\ & & \%^{*} & \\ \text { Law } & 1,600 & 0.4 & \text { average } \\ \text { Non-law university education } & 41,000 & 1.2 & \text { average } \\ \text { University education total } & 42,600 & 1.1 & \text { average }\end{array}$

* yearly as a percentage of employment in 2004

Source: AIS 2005

Table 3.8 presents the expectations for law studies, non-law university education, and total university education. The figures on employment growth indicate that the yearly 
demand caused by expansion of the labour market for all law graduates $(0.4 \%)$ is slightly below that for non-law university education (I.2\%) as well as total university education (I.I\%). Nevertheless, employment for law graduates is expected to grow on an average rate until 20IO. In total, the labour market demands I,600 new law graduates in this period because of labour market expansion.

Table 3.9 shows the demand caused by replacement of employees who leave the labour market. The replacement demand for law graduates is slightly above the demand for non-law university education as well as the demand for total university education. It can be characterized as being average, which implies that the expected replacement rate for graduates is about the same for law graduates as for non-law university education and for total university education. In the period 2005-20IO, II,900 law graduates are needed on the labour market to replace employment.

\section{Table 3.9}

Replacement demand for university graduates, 2005-2010

\begin{tabular}{lccc} 
& Replacement demand & Yearly & Characterisation \\
Law & 11,900 & $\%^{*}$ & \\
Non-law university education & 84,600 & 2.6 & average \\
University education total & 96,500 & 2.5 & average \\
\hline
\end{tabular}

* yearly as a percentage of employment in 2004

Source: AIS 2005

What is the total number of jobs opening up for university graduates who enter the labour market? The number of job openings constitute the total demand for newcomers on the labour market and is generated by the growth of employment (positive expansion demand) and the replacement demand. Table 3.Io indicates that in total, 13,500 vacancies have to be filled by law graduates in the period 2005-20I0. Law graduates turn out to be in a somewhat less favourable position in terms of vacancies $(3.0 \%)$ than their nonlaw university education (3.7\%) and total university education (3.6\%) counterparts.

Table 3.10

Job openings for university graduates, 2005-2010

$\begin{array}{lccc} & \begin{array}{c}\text { Job openings for } \\ \text { newcomers }\end{array} & \begin{array}{c}\text { Yearly } \\ \%^{*}\end{array} & \text { Characterisation } \\ \text { Law } & 13,500 & 3.0 & \text { low } \\ \text { Non-law university education } & 127,000 & 3.7 & \text { average } \\ \text { University education total } & 140,700 & 3.6 & \text { average }\end{array}$

* yearly as a percentage of employment in 2004

Source: AIS 2005

When we examine the supply side of the labour market, we first look at the expected inflow of university education. Table 3.II shows that the expected inflow of law gradu- 
ates on the labour market is only slightly higher (3.1\%) than for non-law university education $(3.0 \%)$ and total university education (3.0\%). Combined with the less favourable position in terms of vacancies, this suggests that law graduates in general occupy a somewhat less favourable labour market position than non-law university education graduates.

Besides predictions for the type of university education, expectations can also be presented for the most prominent occupation for which European Law School is preparing its students: lawyers. Note that lawyers here comprise the occupational profession of lawyers in general, and thus include company lawyers as well. Table 3.12 indicates that the expansion demand for all occupations is expected to grow on average with I.O\% per year until 20IO. For lawyers, this percentage is $0.7 \%$. Although the growth in expansion demand for lawyers is slightly below the overall average growth rate, it still can be classified as average. In general, 2,200 lawyers are needed because of employment growth in the period 2005-2010.

Table 3.11

Inflow of university graduates on the labour market, 2005-2010

\begin{tabular}{lrcc} 
& Inflow & Yearly & Characterisation \\
Law & & $\%^{*}$ & \\
Non-Law university education & 14,000 & 3.1 & average \\
University education total & 103,773 & 3.0 & average \\
\hline
\end{tabular}

* yearly as a percentage of employment in 2004

Source: AIS 2005

Table 3.12

Expansion demand for lawyers, 2005-2010

$\begin{array}{lrcr} & \text { Expansion demand } & \begin{array}{c}\text { Yearly } \\ \text { \%* }\end{array} & \text { Characterisation } \\ \text { Laywer } & 2,200 & 0.7 & \text { average } \\ \text { All occupations } & 371,700 & 1.0 & \text { average }\end{array}$

* yearly as a percentage of employment in 2004

Source: AIS 2005

Table 3.I3 indicates that the yearly growth in expected replacement of lawyers is very low (I.5\%), whereas all occupations in general face an average growth in replacement demand until 2010 (3.0\%). However, 5,300 lawyers are in total required to meet the demand for replacing employees that leave the labour market in the period 20052010 . 
Table 3.13

Replacement demand for lawyers, 2005-2010

$\begin{array}{lrcc} & \text { Replacement demand } & \begin{array}{c}\text { Yearly } \\ \%^{*}\end{array} & \text { Characterisation } \\ \text { Laywer } & 5,300 & 1.5 & \text { very low } \\ \text { All occupations } & 1,149,900 & 3.0 & \text { average }\end{array}$

* yearly as a percentage of employment in 2004

Source: AIS 2005

Again, when we look at the total number of job openings for newcomers (see Table 3.I4), we find that in terms of growth in expected vacancies, lawyers do considerably worse $(2.0 \%)$ than all occupations in general $(4.2 \%)$. Therefore, the yearly rate of job openings for lawyers can be classified as very low, whereas it is labelled average for all occupations in general.

Table 3.14

Job openings for lawyers, 2005-2010

$\begin{array}{lrrr} & \text { Job openings for newcomers } & \begin{array}{c}\text { Yearly } \\ \% *^{*}\end{array} & \text { Characterisation } \\ \text { Laywer } & 7,600 & 2.2 & \text { very low } \\ \text { All occupations } & 1,635,100 & 4.2 & \text { average }\end{array}$

* yearly as a percentage of employment in 2004

Source: AIS 2005

Finally, we examined the expected overall labour market situation for lawyers. Table 3.I5 indicates that no future bottlenecks are expected in the recruitment for lawyers by employers until 20I0. This expectation is based on future demand as well as supply conditions for lawyers. Moreover, we find that changes in the economic situation (sensitivity to the business cycle) are expected to have an average effect on the labour market position of lawyers in the period 2005-20I0. Furthermore, their opportunities in terms of finding employment in other occupations are expected to be average too.

Table 3.15

Labour market expectations for lawyers, 2005-2010

$\begin{array}{lcc} & \text { Indicator } & \text { Characterisation } \\ \text { Problems in recruiting labour } & 0.99 & \text { none } \\ \text { Sensitivity to the business cycle } & 0.96 & \text { average } \\ \text { Oppertunities to switch } & 3.03 & \text { average }\end{array}$

Source: AIS 2005

All in all, the labour market expectations for the period 2005-20I0 are somewhat less favourable for law graduates and lawyers than those for non-law university graduates and other occupations. Moreover, there is no sign of future bottlenecks in the recruitment for lawyers by employers. Nevertheless, the number of job openings for law 
CHAPTER 3

graduates and lawyers is still growing, which makes that European Law School graduates should have sufficient opportunities on the labour market until 20 Io. 


\section{Students' Opinions}

\subsection{Introduction}

To add to the information on recruitment and labour market position described in the previous two chapters, we interviewed students using the method of so-called focus groups. This is a qualitative research technique often used in marketing to investigate consumers' preferences. Focus groups are small groups of - in our case - students, which are stimulated to express and discuss their individual ideas and judgements and to add to each other's opinions. As Table 4.I shows, we interviewed five groups of students. These groups were selected for different reasons and each had a different focus of topics:

\section{Bachelor students of the 'Classic' European Law School}

Bachelor ELS students can offer great insights in the attractiveness of the new English Language Bachelor European Law School as they have experienced the 'classic' system for some years. We therefore interviewed third year bachelor ELS students. Focus of the group discussion was on the new English Language Bachelor European Law School and the present study. In total, we interviewed I 6 bachelor ELS students divided into two groups. Most of them were Dutch, but there were also some German, Belgian, and a Spanish student present.

\section{Master students of European Law School}

Master ELS students were approached to express their opinion on the new English Language Bachelor European Law School as well. Focus of the group discussion was on the labour market position and the new English Language Bachelor European Law School. In total, we interviewed 2 master ELS students: a Dutch and an Estonian student. ${ }^{1}$

\section{Bachelor students of European Studies}

European Studies is an interdisciplinary programme that focuses on the various political, social, and cultural issues associated with the European integration process. As

I. More students were approached to take part in the group interview, but unfortunately, only two students were able to participate. The other students had classes immediately after the tutorial meeting, which was not known to us. 
European Studies students are interested in Europe, many of them considered choosing European law. Moreover, since the programme is taught in English, European Studies attracts quite a few foreign students. We interviewed third year bachelor students, as they are in the process of evaluating their studies and making up their minds about which master to follow. Focus of the group discussion was on the new English Language Bachelor European Law School and the present study. In total, we interviewed 8 bachelor students European Studies: 6 German, I Dutch, and I Belgian student.

\section{Bachelor students of University College Maastricht}

University College Maastricht (UCM) offers a broad range of courses covering the humanities, the social sciences, and the life sciences. Students choose courses following their interests and talents. As some UCM students follow law courses and are interested in the European Law School, they constitute an interesting group to interview as well. Focus of the group discussion was on the new English Language Bachelor European Law School and the present study. In total, we interviewed one first-year student of University College Maastricht, who was Dutch. ${ }^{2}$

\section{Bachelor students of Economics}

The Faculty of Economics and Business Administration is very international and attracts large number of foreign students. $48 \%$ of all new enrolled students come from abroad; most of them are German. ${ }^{3}$ We interviewed first year economics students, as they made the choice to come to Maastricht fairly recently. Focus of the group discussion therefore was on recruitment and Maastricht University. In total, we interviewed 6 bachelor students of Economics: 5 were from Germany and one from Azerbaijan.

\section{Table 4.1}

Group interviews with students

\begin{tabular}{llcl} 
Student group & Date of interview & No. of students & Nationalities* \\
\hline Bachelor ELS & Feb, 7, 2006 & 4 & NL (1), GER (1), B (1), Spain (1) \\
Bachelor ELS & Feb, 14, 2006 & 12 & NL (10), GER (1), B (1) \\
Master ELS & Feb, 16, 2006 & 2 & NL (1), Estonian (1) \\
Bachelor European Studies & Feb, 16, 2006 & 8 & NL (1), GER (6), B (1) \\
Bachelor UCM & Feb, 23, 2006 & 1 & NL (1) \\
Bachelor Economics & Feb, 21, 2006 & 6 & GER (5), Azerbaijan (1)
\end{tabular}

* $\mathrm{NL}=$ Dutch, GER = German, $\mathrm{B}=$ Belgian

The students were first approached by e-mail, which explained the purpose of the interview and included an invitation to participate in a short group interview after their next tutorial meeting. In the e-mail, we stressed that their opinions would be highly valued. At the start of the tutorial meeting, we explained in class that the group interview would take place after the meeting and that they were very welcome to join

2. For logistic reasons, the interview with UCM students was planned before the tutorial meeting. Unfortunately, this resulted in a low turn-up at the time of interview.

3. Website of the Faculty of Economics and Business Administration at www.unimaas.nl. 
the interview. After the tutorial meeting, we escorted students to the interview room in order to make sure that as many students as possible participated in the interview.

We started the interviews with a short introduction of ourselves and the purpose of the interview, followed by an introduction of the new English Language Bachelor European Law School and its major/minor structure. Students were then asked to discuss about the following topics:

- The new English Language Bachelor European Law School: possible alternative, major and minor structure, most and least attractive features, and potential problems;

- The present study: reasons for choice, alternatives considered, most and least attractive features, expectations, and academic expertise and language skills of Maastricht University staff;

- Maastricht University: reasons for choice, alternative universities considered, most and least attractive features, and expectations;

- Recruitment: transmission channels for university and study;

- Labour market position: type of job, work environment, in the Netherlands or abroad, value of Maastricht University diploma, and specificity of study.

As mentioned above, each group focused on different topics. It was stressed that students could express any opinion, positive or negative, they had, and they were encouraged to speak up. After the group discussion, students were asked to fill in a short questionnaire with open-ended questions. This enabled them to express their opinions in a more private way. Appendix B gives a complete overview of the questions asked. Most interviews took about 45 minutes.

\subsection{The New English Language Bachelor European Law School}

When we ask students about their opinion on the new English Language Bachelor European Law School, they almost unanimously think that this is a good idea. This holds for bachelor and master students of the 'classic' European Law School, as well as for students of European Studies, University College Maastricht, and Economics. The general impression is that this new track will provide an interesting alternative, which has the potential to attract more foreign students. However, for the new English Bachelor European Law School to be successful, students believe that a couple of crucial conditions have to be met too.

\section{Civil Effect}

When discussing the English Language Bachelor European Law School, bachelor students of the 'classic' ELS immediately and spontaneously show great concern about the civil effect. They wonder whether a civil effect can be obtained with the 
new programme and how this can be achieved. A vast majority of ELS students thinks that the civil effect is very important ${ }^{4}$, even though most of them will not enrol in so-called 'toga professions'. They feel that a civil effect increases their opportunities on the labour market, especially since they believe that they will have to work within the national law system for a couple of years before they can move on to a more international job abroad.

Moreover, students mention that, when deciding what to study at the end of high school, most school-leavers simply don't know much about European law. They often are unsure whether their expectations will be fulfilled, and therefore, choose for an academic education that leaves many options open. School-leavers want to be able to transfer to another study without losing too much time and effort (i.e. ECTS study points), for example by switching from ELS to Dutch Law. In addition, as they are quite young and often do not yet know where they want to work after graduation, school-leavers do not want to exclude any job options. This means that the civil effect is quite important when deciding to study European Law School or not.

Not only ELS students, but also students of European Studies or Economics believe that the guarantee of a civil effect in the English Language Bachelor European Law School is very important for the success of this new track. Quite a few students considered studying law, and almost all of them would have liked to obtain a civil effect in their national law system. In this respect, the major-minor structure of the new English Language Bachelor European Law School is appealing to Belgian and German students, as this will allow them to study their national law system. German students, however, note that it is quite hard to obtain a civil effect in Germany, for it takes many years of study and difficult exams to pass. This prospect is not very appealing to them, and is one of the major reasons why German non-law students who considered law, choose a non-law study like European Studies or Economics.

All students think that marketing and communication about the civil effect is very important. The Faculty of Law should mention in their PR materials, brochures, and website how the civil effect can be obtained when enrolled in the English Language Bachelor European Law School. This would include a detailed description of which minors and electives to take, which follow-up masters to complete, and which other requirements to fulfil in order to get a civil effect in Dutch law, Belgian law, or German law.

\section{European Law versus National Law}

ELS students explain that their choice for European Law School was largely based on the expectation that they would study European law from the beginning. This

4. Of the I8 bachelor and master European Law School students interviewed, I4 students state that the guarantee of a civil effect after graduation is an important issue to them; 3 students do not think that it is important, and I student has no opinion. 
expectation was not fulfilled, as the first year of the 'classic' ELS programme is entirely devoted to Dutch law. Students feel that this only is an introduction to the real European Law School, which in their opinion genuinely starts in the second or even the third year, when the program focuses more and more on European law in a comparative perspective. They therefore suggest including an introduction into European law in the first year programme of the 'classic' ELS, for example the 'International and European Law' course currently offered in the first period of the second year (course 2.I). They even want to give up the two skills training periods to implement this course in the first year programme.

Keeping this in mind, ELS students are enthusiastic about the new English Language Bachelor European Law School programme, in which courses on European law are offered from scratch. Moreover, students of - for example - European Studies find this early start in European law attractive too, as their prime interest is in European topics. The 'classic' ELS programme with a full first year on Dutch law does not appeal to them, as they find Dutch law quite boring.

However, ELS students very much realize that studying European law is quite difficult without a thorough knowledge of a national law system. They are concerned about the new programme and wonder whether students of the English Language Bachelor European Law School will be able to grasp European law. Or, as one bachelor ELS student puts it: "They will be immediately thrown into the deep without any knowledge of law". Students believe that one needs a frame of reference to see the logic behind different law systems. With a base in a national law system, it is easier to compare systems, as the criteria on which to compare are known. Moreover, students are worried about the limited amount of time spent in the new track on studying a national law system. They wonder whether the English Bachelor European Law School minors will be enough to constitute a firm base in Dutch law, Belgian law, or German law.

\section{General versus Specialized Education}

In general, students like university studies with a broad programme, as they want to leave as many options open as possible and do not want to limit their choices to soon. This especially holds for students who just started their studies, as they often do not have a clear idea about what to do after graduation. Therefore, students of the 'classic' European Law School like the present structure of a common first year together with students of Dutch Law. It postpones their choice whether to continue with ELS or to switch to Dutch Law for another year; students feel that they can make a more mature choice after one year of studying at the university than when they leave high school. The new English Language Bachelor European Law School, on the other hand, starts with European law from scratch. This means that there is no freedom of choice up to the third year. Students are concerned about being too specialized too soon and about the switching possibilities of the new programme. They wonder what happens to new 
students who don't like EELS as much as they thought they would and who want to switch to Dutch Law without losing to much time and effort. Will they be compensated in ECTS points for taking courses in European law? Or will they loose an entire year? Students stress that these consequences should be clearly communicated to the new English Language Bachelor European Law School's students.

All students agree, however, that a bachelor study should not be too broad in the third and final year and that there should be room for specialisation. For example, students of European Studies really liked the idea of a broad study when they started, but now that they are in their third year, they really want to specialize in topics like international business, politics, or law. They feel that the master phase is too late to specialize. In this respect, the major/minor structure of the new English Language Bachelor European Law School programme is very attractive to students. In the third year, they can choose between e.g. Dutch law, Belgian law, or German law.

In addition, the new programme fits to the students' ideal of having great freedom of choice. Students want to follow courses that match their interests and talents, and they want to be able to specialize in a subject they think is appealing. For this reason, students of University College Maastricht are quite satisfied with their studies as they compose their own programme. Students of the 'classic' European Law School and students European Studies on the other hand, follow a mandatory programme with little room of electives. There is no choice of which courses to follow, which makes that these studies are less motivating to students.

\section{Challenging Study}

When starting their studies, bachelor students of the 'classic' European Law School had the impression that they were enrolling in a challenging study, which would require a lot of hard work. Only motivated students were said to choose European Law School, which would be the flagship of the Faculty of Law. The ELS students we interviewed were very disappointed in their expectations, however. The workload turned out to be quite low, and students - at least in the first two years - were not motivated at all. Students think that studying Dutch Law is more difficult, especially since the moot court training is quite demanding. To increase their workload, some bachelor ELS students follow additional courses in Dutch law.

According to the students' opinions, the new English Language Bachelor European Law School should be more demanding than the 'classic' ELS is. Courses should be more in depth, and (international) internships should be made possible. At the same time, students mention that they always are in a hurry to cover all materials in class. They often seem to run out of time in a block period of eight weeks. This calls for a more balanced content of courses. 
Again, students believe that marketing about the new English Language Bachelor European Law School should be clear. If the study is demanding, this should be communicated, but if it is not, than there is no reason to call EELS the flagship of the Faculty of Law. Unclear communication only sets wrong expectations, which, in turn, decrease students' motivation. In this respect, students do not think that selection at the gate is a good idea; they want to leave the English Language Bachelor European Law School open to any student. However, to attract more motivated students, they recommend that new students write a motivational letter. They believe that this is a hurdle that unmotivated students will not take.

\section{Internationalisation}

Bachelor students of the 'classic' European Law School make very clear that ELS is not as international as they thought it would be. First of all, there are hardly any foreign students. As the new English Language Bachelor European Law School has the objective to attract more students from abroad, all students think this is a good idea. A mix of 50\% Dutch students and 50\% foreign students seems to be perfect to them, as this would create an international study environment. One student notices that 'international' in fact means 'Euregional', as Maastricht University mainly attract students from Germany and Belgium. The new English Language Bachelor European Law School would predominantly attract students from these two countries as well, as it intends to offer minors in German law and Belgian law.

Secondly, students had the impression that foreign languages were very important when studying European Law School. Not only are some of their classes in English, passive knowledge of German and French would also be required. However, students never came across any study material in those languages, nor do they think that they will use German or French in their studies at all. They nevertheless believe that the major appeal of the new English Language Bachelor European Law School lies in teaching all courses in English, as this will attract students who are more internationally oriented. Students of European Studies, University College Maastricht, and Economics fully agree with that. Some foreign students even mention that they would have chosen the English Language Bachelor European Law School if it had been a possible option at the moment they had to decide what to study.

Finally, the 'classic' European Law School is not as international as students thought it would be, because the programme does not include a study period or internship abroad. Bachelor ELS students had the impression that they could go to another country for a semester, but this turned out not to be the case. Students who want to study at a foreign university or who want to do an internship at for example the European Commission, the International Criminal Court, or the World Trade Organisation, simply have to this in their own time. This means that either their bachelor study will be delayed, or - in the case that they go abroad after their bachelor degree graduation - that they start their master's programme at least half a year later. 
Students indicate that they do not want to wait for their master study to go abroad. ${ }^{5}$ Bachelor ELS students think that offering a study period or internship abroad would be a key attraction of the new English Language Bachelor European Law School. They are quite disappointed when they hear that this is not intended to be part of the programme. Students of European Studies, University College Maastricht, and Economics also think that going abroad for study or internships during their bachelor studies is one of its major appeals. In fact, almost all Economics students choose Maastricht University for this reason. They go abroad for one semester in the second year of their studies, but even prefer this period to be longer.

All in all, students stress that PR and marketing about the international aspects of the new English Language Bachelor European Law School is very important when attracting more foreign students. The Faculty of Law should not raise wrong expectations, but should be honest in their communication. In this way, the English Language Bachelor European Law School would also attract more internationally oriented students.

\subsection{Recruitment}

Recruitment obviously plays a key role in the intake of new students. It therefore is important to know how students heart about Maastricht University, and how they got information about their studies. The answers to these questions might help the Faculty of Law in their recruitment of students for the new English Language Bachelor European Law School.

The ROA report 'School-leavers between education and labour market' shows which sources of information school-leavers of pre-university education use when deciding which university study to follow. ${ }^{6}$ Table 4.2 illustrates that $90 \%$ of school-leavers visited an open day, $8 \mathrm{I} \%$ read printed brochures, and $74 \%$ used the Internet. About half of them received support from their high school, for example from a teacher, mentor, or student councillor. $36 \%$ visited an experience day at the university, during which school-leavers are given the opportunity to find out what a specific study programme is all about by attending classes in the future study environment and by asking questions to teachers and students. When asked which source of information was the most useful in the decision process, about half of the students mention the open day. $20 \%$ say that brochures were most of use, whereas one out of ten mentions the Internet.

5. For example, the master 'Law and Languages' offers a mandatory half-year period abroad in which students study at one of the partner universities of Maastricht University.

6. ROA (2005), Schoolverlaters tussen onderwijs en arbeidsmarkt, ROA-R-2005/6, Maastricht. 
Table 4.2

Sources of information used by school-leavers of pre-university education when deciding what university study to follow

$\begin{array}{lcc}\text { Sources of information } & \text { Used } & \text { Most useful } \\ & \% & \% \\ \text { Open day } & 90 & 48 \\ \text { Brochure } & 81 & 20 \\ \text { Internet } & 74 & 10 \\ \text { Support at school (teacher, mentor, student councillor) } & 51 & 9 \\ \text { Experience day } & 36 & 7 \\ \text { Other } & 17 & 5\end{array}$

* Because students could use more than one source, the percentages do not add up to 100 Source: School-leavers between education and labour market, ROA-R-2005/6

The discussions in the group interviews make clear that European Law School students use the same recruitment channels as other students do. Most Dutch students went to one of the open days of the university, which are organised each year in March and November. They also got advice from student advisors at their high school, and read printed brochures or information on the Internet. Some students visited the 'Studie Beurs' in Utrecht, a four-day study fair organized each year in October. At this study fair, about 300 institutes of higher education present themselves to school-leavers. A few students mention that their high school arranged a so-called educational market for their pupils, at which higher vocational colleges and universities provide information about studies they offer.

Foreign students, on the other hand, primarily seek information on the Internet. They use search engines like 'Google', or find information on the website of Maastricht University. German students also mention the website 'www.studiereninholland.de', which contains a lot of information on studying in the Netherlands. In addition, several German students visited the 'Einsteig Abi Messe' in Cologne, a study fair that resembles the Dutch 'Studie Beurs' in Utrecht. Other 'Einsteig Abi Messe' take place in Karlsruhe, Berlin, and Munich, but none of the students interviewed visited those study fairs. Finally, some foreign students read printed brochures that were sent to their home university or high school.

Another important information channel for new students not mentioned before are their friends and relatives who already study at Maastricht University. Both Dutch and foreign students highly value the opinion of their acquaintances. Students follow their advice, and most of them came to Maastricht because friends and relatives were very positive about Maastricht University or the study. Moreover, many foreign students do not come to Maastricht on their own, but are accompanied by friends who often choose the same study. 


\section{Other Universities and Studies Considered}

Almost all European Law School students considered other universities before deciding to study at Maastricht University. However, there is not much choice in the Netherlands if one wants to study European law. Dutch students mainly thought about studying law at other Dutch universities, but in general liked the educational system of Maastricht University best. Some considered the Free University of Amsterdam or the University of Amsterdam, but had the impression that these universities are very large scaled and quite chaotic. Utrecht University and Tilburg University were not chosen because of a poorer reputation (e.g. low level law courses), whereas the Radboud University of Nijmegen was said to be dropped because the city didn't look as nice as Maastricht.

Foreign students do not have many options to study European law either. According to German students, no genuine alternative for ELS exists in Germany. Some of them considered studying at German universities, like the Freie Universität Berlin or the University of Dortmund, but in general, the number of students at German universities is very large and the student facilities are not very good. Moreover, in the students' opinions, the reputation of German universities is not as good as the reputation of Maastricht University. Other alternatives considered were private German universities, which are smaller and better, but very expensive. Belgian students also considered studying at their national universities, like the University of Namen or the University of Brussels, but these universities are thought to be not as innovative as Maastricht University.

In general, foreign students look for universities that teach (most of their) courses in English. Therefore, universities in the United Kingdom are very appealing to students. This is even more the case for law students, who obtain a civil effect in British law after graduating from a bachelor study in the UK. Students mention the University of Birmingham and King's College in London as alternatives. However, British universities are not easy to enrol in, as they often require passing an entry exam. Private universities also charge a high tuition fee.

Next to studying Dutch Law, several bachelor students of the 'classic' European Law School considered other studies as well. For example, a few students thought of studying International Business at the Faculty of Economics and Business Administration. Other alternatives were University College Maastricht or European Studies, as these studies include European law as well. However, students believe the perspectives on the labour market to be worse after graduating from these latter two studies. Moreover, University College Maastricht and European Studies do not provide a civil effect, which is very important for European Law School students.

It is also interesting to note that about half of the European Studies students interviewed considered studying European Law School. They eventually did not choose 
ELS because they believe that one needs to be competent in a national law system in order to work in the field. For non-Dutch speaking students, the 'classic' European Law School was not an option as its first year is entirely taught in Dutch. Some students of European Studies mention that they are more interested in European law now (when they are in the third year of their studies) than when they started to study.

\section{Positive Aspects of Maastricht University}

When asked about the positive aspects of Maastricht University, students come up with a long list of attractive features. Most often mentioned are the educational system of Problem Based Learning, and the small scale of the university. Students also find the international atmosphere, the excellent student facilities, and the easy admission to the university valuable assets. Finally, the city of Maastricht is very appealing to them.

- Problem Based Learning System

Many students (both Dutch and foreign) mention that they chose Maastricht University because of the distinctive educational system: Problem Based Learning (PBL). In this system, students study real-life problems in small groups. First, they, together with their fellow students, analyse a problem and discuss what is needed to solve it. After a period of individual studying, the group members meet again to report their findings. A tutor sits in on these group meetings to guard the process and to monitor the level of the discussions. ${ }^{7}$ Students believe that this PBL system asks more of students: active group participation is required and students have to put in more effort. This makes that students are more motivated and more interested in the subject taught.

In addition, the PBL system teaches students important generic academic skills as well. A survey among employers of Maastricht University graduates of the Faculty of Economics and Business Administration ${ }^{8}$ shows that employers recognise these skills, as they state that Maastricht University graduates clearly score above average with respect to interpersonal skills and problem solving skills. Most of them believe that differences between Maastricht University graduates and other graduates are related to Problem Bases Learning. In total, $64 \%$ of the employers know about the PBL system at Maastricht University.

Students therefore believe that the PBL system is a major attraction of Maastricht University and should definitely be included in the marketing strategy of the new English Language Bachelor European Law School. Problem Based Learning, however,

7. See www.unimaas.nl.

8. Allen, J. \& G. Ramaekers (2006), Survey among employers of alumni from the Faculty of Economics and Business Administration of Universiteit Maastricht, ROA-R-2006/IE, Maastricht. 
has some drawbacks too. First of all, bachelor students of the 'classic' European Law School mention that Problem Based Learning is not always strictly followed. They regret this, as PBL makes courses more interesting.

Secondly, the PBL system stands or falls with the active participation of students. ELS students were quite disappointed in the first two years of their study, as many of their fellow students didn't speak up at all. However, now that they are in their third year, students think that their counterparts are quite motivated, which makes that the PBL system works better. In order to increase active student participation during group meetings, a participation grade or peer review could be introduced at the Faculty of Law. When students know that they are evaluated on their participation in the group, they will increase their efforts.

Finally, competent tutors are essential to make the PBL system work. Most students are quite satisfied with the academic and teaching skills of their tutors, although they do mention that the level of skills depend on the tutor. Some students, however, believe that more professional teaching staff is needed. Or, as one student puts it: "Teachers are needed instead of tutors". Students particularly complain about the competency of tutors in the first years of their studies. Tutors of third year courses are believed to be much more academic and experienced in teaching.

\section{- Small Scale University}

Another major appeal of Maastricht University is its small scale. Not only do students work in small groups because of the PBL system, the 'classic' European Law School attracts a reasonable small number of students each year (see also Table I.I in chapter I). Third year bachelor ELS students mention that they now constitute a group of approximately 80 people, which means that students know each other quite well. They like the familial atmosphere, but stress that this was not the case in the first year of their studies, when they shared their programme with Dutch Law students. In total, the Faculty of Law has about 2,0oo students. Especially German students enjoy the small scale of the university, as most German university courses have the reputation of being crowded with students.

Another advantage of the small scale of Maastricht University is that student-staff relations are very good. Students think that tutors and professors are very studentfriendly, easy to approach, and not arrogant at all. As one student writes down: "When you have problems, you can always contact them for help". Foreign students often mention that the distance between students and academic staff is short. On the one hand, this might be explained by referring to Dutch cultural manners, which are rather informal. On the other hand, it might also be caused by the fact that Maastricht University is a young university. The Faculty of Law started its activities in September 1982, and the 'classic' European Law School opened in 1995. Although the university is quite young, it has a good reputation in the Netherlands and abroad. Most students 
mention that Maastricht University has a good name, and that this high standing also was one of the reasons why they chose for Maastricht. A few Dutch ELS students, however, sense that Maastricht University is not as renown as one of the 'old' universities. For example, Leiden University has a big name in law, and Maastricht University still has to build up its reputation in this respect.

- International Atmosphere

Students like the international atmosphere at Maastricht University. Far more than at other Dutch universities, students from different national backgrounds come to Maastricht to study. At this moment, the Faculty of Law attracts 10\% of its students from abroad. Of course, the English Language Bachelor European Law School has the aim to increase this intake of foreign students. As mentioned before, students think a mix of $50 \%$ Dutch students and 50\% foreign students to be perfect. They, however, stress that in order to be a genuinely international university, foreign students should not simply and solely have German or Belgian nationalities, but be residents from other countries too.

Both Dutch and foreign students find it attractive that many courses at Maastricht University are taught in English. The new English Language Bachelor European Law School will certainly add to this appeal. Students see English language courses as a way to improve their English language skills too. In this respect, students of Economics would like to see that English courses are included in the regular study programme. They particularly miss language courses to improve their pronunciation skills. In general, the English language skills of academic staff are thought to be sufficient. Students, however, emphasise that it depends on the tutor; according to them, some tutors have difficulties speaking English in class.

\section{- Student Facilities}

All students agree that student facilities at Maastricht University are very good. The library is well equipped, and there is additional information accessible in the learning resource centres. Computers with high-speed Internet access are available and each student gets a university login and e-mail account. Courses are taught using the electronic learning environment of Maastricht University (ELEUM), which is a blackboard learning system on which course materials and announcements are posted. ELEUM also facilitates students to start discussion groups, and to hand in their assignments electronically. In particular, German students like the student facilities of Maastricht University, as they observe that these are not of such a high quality at German universities.

In addition, student life is considered to be very good. There are a lot of students' associations, from sports clubs to fraternities. There is no campus, however. This would be an area where all university and surrounding buildings are situated, usually including 
libraries, lecture halls, and student residential areas. Some students think this lacking is a pity.

\section{- Easy admission}

Another positive aspect of Maastricht University is the easy admission, especially when compared to universities abroad. No special selection of European Law School students takes place. As mentioned before, ELS students think this is a good idea, as they want to leave the study open for all students. Moreover, students do not have to take an entry exam; a high school certificate equal to the Dutch pre-university (VWO) diploma suffices. However, in order to enrol in the 'classic' European Law School, non-Dutch speaking students need to pass a Dutch language test, as all courses in the first year are taught in Dutch. Since the new English Language Bachelor European Law School is taught in English, a Dutch language test will not be required. Finally, because European Law School has no numurus clausus, there is no limit to the amount of students that are allowed to enrol.

Next to the absence of any selection procedures, studies at Maastricht University are easy to enrol in because of low tuition fees. For the academic year 2005/2006, the annual tuition fee was $€ \mathrm{I}, 496$, which is much lower than private universities in for example the United Kingdom or Germany charge. In addition, foreign EU students can apply for partially refunding of this tuition fee. They are also entitled to a study grant from the Dutch government if they have a job of at least 32 hours a month. This study grant is about $€ 240$ a month and gives access to free public transport in the Netherlands as well. 9

- City of Maastricht

Last but not least, the city of Maastricht turns out to be very appealing to students. The city is one of the oldest cities in the Netherlands and has many beautiful buildings. The Faculty of Law is situated in the inner city, which most students find very attractive. Maastricht also is a relatively small city, even for Dutch standards. In total, it has about I25,000 inhabitants with a student population of II,500. Students like this small scale environment, as everything is neatly arranged and well-organized. Facilities can be easily reached by foot or by bike. Student life also is very good in the students' opinions.

Moreover, Maastricht is situated near the German and Belgian border. This means that these countries are close in proximity, which makes it attractive for German and Belgian students who like to study not too far from home. However, for other students, the proximity is unattractive feature, as they want to study in a different environment not too close to their hometown.

9. This study grant is eligible for a period of four years maximum. 


\section{Negative Aspects of Maastricht University}

Interestingly, students found it much more difficult to think about negative aspects of Maastricht University. Several students were even not able to mention one unattractive feature, which implies that they are quite satisfied. There are some 'minor' issues that come up in the group discussions, though.

First and foremost, students complain about the bureaucracy at Maastricht University. Especially for foreign students, it takes a while before their application is final and everything (UM card, e-mail account, login etc.) is arranged. Students mention that student services and the 'Onderwijsbalie' are not very student friendly. As one student puts it: "They should be there to help students, but they only cause more problems". On top of that, students of European Studies think that people at the Language Centre are not very competent and helpful.

Although students stress that student facilities are excellent at Maastricht University, they think that the library is quite crowded. More workplaces to study would be highly appreciated. In addition, students think that the range of studies offered at Maastricht University is rather limited. One can choose for Law, Economics and Business Administration, Arts and Culture, General Sciences, Medicine, or Health Sciences. Students would like to see more courses and studies offered in Maastricht, especially in the fields of social sciences, philosophy, and languages.

As mentioned before, the city of Maastricht is quite small. Some students like this very much, whereas others would like to live in a metropolitan with the grandeur of a big city. Moreover, housing is quite expensive in Maastricht. In particular, German students complain about the rent for accommodation. It also is not so easy for students to find a nice, not-to-expensive room or apartment. Several foreign students therefore think it is a pity that the university is not situated on a campus, as this would include affordable student housing.

Finally, foreign (especially German and Belgian) students complain about the parking policy of the city of Maastricht and Maastricht University. In contrast to Dutch students, most of German and Belgian students have a car, which they are not allowed to park at the university's car park unless they are disabled. ${ }^{\text {Io }}$ In the inner city of Maastricht, parking spaces are limited and cost money.

IO. A doctor's attest is required to get access to the university's car park. After 17:00 on weekdays and Saturdays, students are allowed to park their car at the university's car park if they get permission from their director. 


\subsection{Labour Market Position}

In the group interviews, we also asked students about their labour market position. As most of them are in the bachelor phase of their academic studies, we first wanted to know whether or not students intend to continue their educational careers by following master programmes. After a discussion on which masters they would prefer and where they would like to study, we enquired about the jobs they would like to take after graduation. Finally, we asked students how they value their Maastricht University degree.

\section{Master Programmes}

All students interviewed do not want to enter the labour market after their bachelor studies, as they think career opportunities are very low for bachelor graduates. They want to continue their academic careers by following a master programme. Most bachelor students of the 'classic' European Law School intend to choose the European Law School Master, because they think this master programme is the most interesting. Some ELS students, however, believe that the European Law School Master is not sufficient to succeed on the labour market. They will switch to the Dutch Law Master, as this - in their opinion - gives them more options and opportunities.

In this respect, it is interesting to note that almost all bachelor ELS students want to stay in Maastricht for their master. Students mention that they know the educational system and the people at Maastricht University. Next to this familiarity with the university, they have strong social ties (friends and acquaintances) that keep them in Maastricht. Moreover, several students note that it is not so easy to switch to a university abroad, as not all EU countries have implemented the bachelor-master structure yet.

The majority of bachelor students of Economics and European Studies, on the other hand, want to go abroad for their master studies. They find it attractive to experience a different cultural climate and would like to live in a larger city. Moreover, students of European Studies indicate that they want to specialise in their master studies, as their bachelor programme is very broad - too broad in their opinion. They do not think Maastricht University offers such specialised masters and are therefore looking across the borders. The United Kingdom in particular appeals to them, as the reputation of British universities is very high, and all courses are offered in English.

However, when students of European Studies hear about the master programmes offered at the Faculty of Law, they are genuinely interested. Masters like Globalisation and Law, Law and Languages, and the European Law School Master perfectly fit in their profile of getting more specialised, and they like the topics taught. Students simply did not know that these options were available at Maastricht University. They mention that they received very little information about masters at other faculties than 
the Faculty of Arts and Culture. They feel that the faculties at Maastricht University are strong competitors of each other, and do not cooperate as much as students would like. All in all, bachelor students of European Studies definitely would like to get more information about law masters at Maastricht University, and about the requirements they have to meet in order to be able to enrol. For example, for the masters mentioned above, students of European Studies need to pass an entrance exam in European and international law. Moreover, a major in law is recommended.

\section{National versus International Jobs}

Where do students of European Law School want to work after graduation? About half of the students interviewed would like to work abroad, for example at the legal department of a large company or multinational. Some students would like to work in a EU institution or in a diplomatic environment like a national embassy. However, the majority of students believe that they need work experience in their national law system first, before being able to find a job abroad. Therefore, the civil effect is very important to them.

Most European Law School students want to become company lawyers. Some think about working in the so-called 'togaberoepen', as they want to become a lawyer or a judge in a Dutch courtroom. The Dutch government is mentioned as an employer too. Students would like to work at the Ministry of Foreign Affairs or the Netherlands Competition Authority (NMa). A single ELS student wants to become a manager.

\section{Value of Maastricht University Degree}

The majority of European Law School students think that their degree will make it possible to work not only in (European) law, but in various related fields as well. They mention that law also teaches many other aspects of life, like social affairs, finance, and economics. In addition, some students followed elective courses in other topics. They think that this will enable them to work outside the traditional law professions. ${ }^{\text {II }}$ It indicates that students believe that European Law School is a rather general study.

Finally, we asked students: do you think that your Maastricht University diploma will enable you to find the job you would like to perform? The vast majority of European Law School students think this is indeed the case. They are fully confident that they will find an interesting job after graduation. Only German students are a little pessimistic as they think the labour market in Germany is not very good in general.

II. Please note that most ELS students do not want to work outside the field of law, though. 



\section{Appendix A Classification of University Studies}

Table 1

Classification of university studies*

\begin{tabular}{ll} 
English & Dutch \\
European Law School & \\
European Law School & European Law School \\
& European Law School \\
International and European Law & \\
International and European Law & Internationaal en Europees recht \\
International Law & Internationaal en Europees recht \\
International Legal Education & Internationaal recht \\
European Legal Education & Internationaal-juridische opleiding \\
International / European Judiciary Law & Europees-juridische opleiding \\
& Nederlands recht, internationale / \\
& Europese rechteljke opleiding \\
Dutch Law & \\
Dutch Law & Nederlands recht \\
Notaries Law & Nederlands recht \\
Notaries Education & Notarieel recht \\
Tax Law & Notariële opleiding \\
Tax Legal Education & Fiscaal recht \\
Legal Administratieve Education & Fiscaal-juridische opleiding \\
Legal Political Education & Juridische bestuurswetenschappelijke opleiding \\
Non-Law University Education & Juridisch-politiekwetenschappelijke opleiding \\
Economics & \\
Social Sciences & Niet-rechten studies \\
Medical Sciences & Economie \\
Agricultural Sciences & Sociale wetenschappen \\
Natural Sciences & Medische wetenschappen \\
Educational Sciences & Landbouw \\
Languages and Cultural Sciences & Natuurwetenschappen \\
Engineering & Onderwijskunde \\
& Taal en cultuurwetenschappen \\
\hline
\end{tabular}

* All studies are at the university level 



\section{Appendix B Group Interviews with Students: Topics and Questions}

A) Your nationality

B) Regarding English Language Bachelor ELS

- What do you think of the new English Language Bachelor European Law School?

- Do you think it is an attractive alternative? Would you choose this study? What do you think of the major and minors in the new ELS?

- What is the most attractive feature of the English Language Bachelor ELS?

- What is the least attractive feature of the English Language Bachelor ELS?

- What do you think might be problematic when you see the new program?

C) Regarding your study

- Why have you chosen to subscribe for this specific study (e.g. personal interest /career)?

- What studies did you consider as well? Why did you not choose for them?

- What is the most attractive feature of the study?

- What is the least attractive feature of the study?

- What did you expect of the study and were your expectations fulfilled?

- What do you think of the academic expertise of the UM staff (good teachers/ know a lot about the content/good researchers/good in giving practical examples/stimulating)?

- What do you think of the English language skills of the UM staff?

D) Regarding your labour market position

- Where would you like to work? Large company/multinational/the government/EU/ In the Netherlands or abroad (e.g. Europe)?

- In what profession would you like to work (e.g. institution/organization/job description)?

- Is the guarantee of a civil effect after graduation an important issue for you?

- Do you think that your UM diploma will enable you to find the job you would like to perform?

- Do you think that your study has educated you for a specific labour market field, or does it enable you to find a job in other (related) fields as well? 
E) Regarding recruitment

- How did you hear about Maastricht University (i.e. transmission channels)?

- How did you hear about the specific study (i.e. transmission channels)?

F) Regarding Maastricht University

- Why have you chosen to enrol at Maastricht University (e.g. international/ innovative character/PBL system/small groups/English program/good reputation/ proximity/city of Maastricht/personal reasons)?

- What other universities did you consider and why were they less attractive?

- What is the most attractive feature of Maastricht University?

- What is the least attractive feature of Maastricht University?

- What did you expect from Maastricht University and did your expectations become fulfilled?

The order of topics/questions depended on the student group interviewed:

Bachelor students European Law School: A - B - C - D - E - F;

Master students European Law School: A - D - B - E - F - C;

Bachelor students European Studies: A - E - F - B - C - D;

Bachelor students University College Maastricht: A - C - B - F - E - D;

Bachelor students Economics: A - E - F - B - C - D. 